\title{
Long-term monitoring programme of the hydrological variability in the Mediterranean Sea: a first overview of the HYDROCHANGES network
}

\author{
K. Schroeder ${ }^{1, *}$, C. Millot ${ }^{2}$, L. Bengara ${ }^{3}$, S. Ben Ismail ${ }^{4}$, M. Bensi ${ }^{5}$, M. Borghini ${ }^{1}$, G. Budillon ${ }^{6}$, V. Cardin ${ }^{5}$, \\ L. Coppola ${ }^{7,8}$, C. Curtil ${ }^{9}$, A. Drago ${ }^{10}$, B. El Moumni ${ }^{3}$, J. Font ${ }^{11}$, J. L. Fuda ${ }^{2}$, J. García-Lafuente ${ }^{12}$, G. P. Gasparini ${ }^{1}$, \\ H. Kontoyiannis ${ }^{13}$, D. Lefevre ${ }^{2}$, P. Puig ${ }^{11}$, P. Raimbault ${ }^{2}$, G. Rougier ${ }^{2}$, J. Salat ${ }^{11}$, C. Sammari ${ }^{4}$, J. C. Sánchez \\ Garrido $^{12}$, A. Sanchez-Roman ${ }^{12}$, S. Sparnocchia ${ }^{14}$, C. Tamburini ${ }^{2}$, I. Taupier-Letage ${ }^{2}$, A. Theocharis ${ }^{13}$, \\ M. Vargas-Yáñez ${ }^{15}$, and A. Vetrano ${ }^{1}$ \\ ${ }^{1}$ CNR-ISMAR, Forte Santa Teresa, 19036 Pozzuolo di Lerici, La Spezia, Italy \\ ${ }^{2}$ Aix-Marseille Univ., Mediterranean Institute of Oceanography (MIO), 13288 Marseille cedex 09, France; Université du Sud \\ Toulon-Var, 83957 La Garde cedex, France; CNRS/INSU, MIO ,UMR 7294, 13288 Marseille cedex 09, France; IRD, MIO, \\ UR235, 13288 Marseille cedex, France \\ ${ }^{3}$ Université Abdelmalek ESSAADI, FP - Larache, Morocco \\ ${ }^{4}$ Institut National des Sciences et Technologies de la Mer (INSTM), 28 rue 2 mars 1934 Salammbo, 2025, Tunisia \\ ${ }^{5}$ Istituto Nazionale di Oceanografia e di Geofisica Sperimentale, Borgo Grotta Gigante, 42/c, 34010, Sgonico (Trieste), Italy \\ ${ }^{6}$ Università degli Studi di Napoli "Parthenope", Dipartimento di Scienze per l'Ambiente, 80143 Napoli, Italy \\ ${ }^{7}$ Université Pierre et Marie Curie (UPMC), UMS829, Observatoire Océanologique de Villefranche-sur-Mer, 06234 \\ Villefranche-sur-Mer, France \\ ${ }^{8}$ CNRS/INSU, UMS829, Observatoire Océanologique de Villefranche-sur-Mer, 06234 Villefranche-sur-Mer, France \\ ${ }^{9} \mathrm{CPPM}$, Aix-Marseille Université, CNRS/IN2P3, Marseille, France \\ ${ }^{10}$ Physical Oceanography Unit, IOI-Malta Operational Centre, University of Malta, Msida MSD08, Malta \\ ${ }^{11}$ Institut de Ciències del Mar (CSIC), Passeig Marítim de la Barceloneta, 37-49, 08003, Barcelona, Spain \\ ${ }^{12}$ Physical Oceanography Group, University of Málaga, Málaga, Spain \\ ${ }^{13}$ Hellenic Centre for Marine Research, 46.7 km Athens-Sounio Avenue, 19013, Anavyssos, Greece \\ ${ }^{14}$ CNR-ISMAR, Viale Romolo Gessi 2, 34123 Trieste, Italy \\ ${ }^{15}$ Instituto Español de Oceanografía, Centro Oceanográfico de Málaga, Puerto pesquero s/n, 29640, Fuengirola, \\ Málaga, Spain \\ *now at: CNR-ISMAR, Arsenale - Tesa 104, Castello 2737/F, 30122 Venezia, Italy
}

Correspondence to: K. Schroeder (katrin.schroeder@ismar.cnr.it)

Received: 13 March 2012 - Published in Ocean Sci. Discuss.: 19 April 2012

Revised: 30 January 2013 - Accepted: 21 February 2013 - Published: 19 March 2013

\begin{abstract}
The long-term monitoring of basic hydrological parameters (temperature and salinity), collected as time series with adequate temporal resolution (i.e. with a sampling interval allowing the resolution of all important timescales) in key places of the Mediterranean Sea (straits and channels, zones of dense water formation, deep parts of the basins), constitute a priority in the context of global changes. This led CIESM (The Mediterranean Science Commission) to sup-
\end{abstract}

port, since 2002, the HYDROCHANGES programme (www. ciesm.org/marine/programs/hydrochanges.htm), a network of autonomous conductivity, temperature, and depth (CTD) sensors, deployed on mainly short and easily manageable subsurface moorings, within the core of a certain water mass. The HYDROCHANGES strategy is twofold and develops on different scales. To get information about long-term changes of hydrological characteristics, long time series are needed. 
But before these series are long enough they allow the detection of links between them at shorter timescales that may provide extremely valuable information about the functioning of the Mediterranean Sea. The aim of this paper is to present the history of the programme and the current set-up of the network (monitored sites, involved groups) as well as to provide for the first time an overview of all the time series collected under the HYDROCHANGES umbrella, discussing the results obtained thanks to the programme.

\section{Introduction}

Due to its relatively small size and its geographical location, enclosed between continents, the Mediterranean Sea is very sensitive and responds relatively rapidly to atmospheric forcings and/or anthropogenic influences, compared to oceanic timescales. Demographic growth, climate change and overexploitation of marine resources are exerting exceptional pressure on the Mediterranean environment, its ecosystems, services and resources. Further, it is a region where major oceanic processes occur, though on smaller scales than those occurring in the world ocean, as for instance the dense water formation (DWF) and the thermohaline circulation, known as the conveyor belt. For these reasons it has often been defined as an ideal test domain for climatic studies (e.g. Garrett et al., 1993). Significant long-term changes of the hydrological characteristics (potential temperature, $\theta$, and salinity, $S$ ) have been reported during the last decades (since the 1960s) in both the Western Mediterranean (WMED) and the Eastern Mediterranean (EMED), essentially for the waters formed inside the two basins and found at intermediate and deep levels (the Mediterranean Waters, or MWs), but also for the surface water of Atlantic origin (Atlantic Water, or AW).

This paper aims at presenting a review of the Mediterranean Sea variability by analysing hydrological time series collected within different water masses all around the Mediterranean in the framework of the CIESM (Mediterranean Science Commission) HYDROCHANGES network (HC hereafter, http://www.ciesm.org/marine/programs/ hydrochanges.htm). Some of these time series have already been studied, entirely or partially, in a number of scientific papers, while others are presented and discussed here for the first time. For sure it is a novelty that all partners have concurred to provide an overall presentation of all series together, giving a significant contribution to the understanding of the degree of variability, in space and in time, of hydrological properties on the long-term in the Mediterranean.

In this introductory section a review of the Mediterranean Sea functioning and its variability is given, and some issues related to the monitoring of long-term hydrological variability are discussed. In the remainder of the paper, we review the rationale behind the HC programme, as well as the history and the present status of the network (Sect. 2). Sections 3 and 4 are dedicated to the presentation and the discussion of the observations collected so far in the HC framework. Section 5 points out improvements that are envisaged and provides some concluding remarks.

\subsection{Mediterranean Sea functioning and documented variability}

The Mediterranean basin-wide thermohaline circulation cell is an open cell, driven by the net buoyancy flux toward the atmosphere that takes place over the sea: the thermohaline circulation starts in the Strait of Gibraltar with the inflow of AW and ends at the same site with an undercurrent of intermediate and deep MWs. Schematically, the AW enters the Mediterranean in the surface layer at Gibraltar, it follows then an anticlockwise circuit in both basins, and is progressively transformed into MWs in the northern parts of the sea during wintertime. Sooner or later these intermediate and deep waters end up exiting the Mediterranean at depth through Gibraltar. The upper branch that carries the AW towards the interior of the sea is a superposition of interacting large-scale and mesoscale patterns (e.g. Pascual et al., 2007), each of them showing their own variability (circulation schemes are given e.g. in Schroeder et al., 2012). In the lower branch the Levantine Intermediate Water (LIW), formed in the EMED, moves at intermediate depths, and is thus able to flow through the Sicily Channel into the WMED without major topographic constrictions. In addition, during milder winters the DWF areas see the formation of other intermediate water masses (e.g. the Western Intermediate Water, WIW, and the Cretan Intermediate Water, CIW, see Millot, 2013) that participate in the lower branch circulation. The deep cells of the two basins are separated by the topography of the channel and driven by DWF processes in the northern parts of the sea: the Eastern Mediterranean Deep Water (EMDW) is formed within the Adriatic or Aegean, while the Western Mediterranean Deep Water (WMDW) is formed in the northern WMED. The naming of these water masses (and others that will be mentioned throughout the paper) follows the recommendations given by CIESM (2001). All acronyms used in the paper are given in Table 1.

In the EMED, dramatic changes in the thermohaline properties and circulation occurred during the late 1980s and early 1990s, when the location of the source of the EMDW shifted abruptly from the Adriatic subbasin to the Aegean subbasin (see e.g. Roether et al., 1996, 2007; Klein et al., 1999; Lascaratos et al., 1999). This event, known as the Eastern Mediterranean Transient (EMT) induced a change in the thermohaline properties and in the circulation of the Ionian subbasin (Malanotte-Rizzoli et al., 1997, 1999; Pinardi et al., 1997) leading to significant changes in the EMDW characteristics. The competition between the two sources of deep waters (Adriatic Deep Water, AdDW, and Cretan Deep Water, $\mathrm{CDW}$ ) is presently favouring again the Adriatic as the main source of EMDW, producing denser water than the 
Aegean. It is still controversial whether the EMT has been an unprecedented phenomenon or not, due to the scarcity of historical data sets, but Josey (2003) reported that similar strong heat flux anomalies occurred also during the 1970s. Recent studies (Rubino and Hainbucher, 2007; Roether et al., 2007; Cardin and Gačić, 2008; Cardin et al., 2011; Bensi et al., 2013) indicate a noticeable salt/heat increase in the intermediate layer of the southern Adriatic between 2003 and 2008, favouring the formation of AdDW (and consequently EMDW in the Ionian abyssal plain), saltier and warmer than before and during the EMT. On the long-term, Tsimplis and Baker (2000) found statistically significant $\theta$ increasing trends in the deep Ionian and in the Levantine subbasins $\left(0.002{ }^{\circ} \mathrm{C} \mathrm{yr}^{-1}\right.$ and $0.001{ }^{\circ} \mathrm{C} \mathrm{yr}^{-1}$, respectively) at $3000 \mathrm{~m}$ from 1960 to 1991. At intermediate levels, Rohling and Bryden (1992) reported an increase in $S$ in the LIW in the Ionian subbasin at a rate of $0.002 \mathrm{yr}^{-1}$ between 1909 and 1990 and of $0.005 \mathrm{yr}^{-1}$ between 1955 and 1990. Interestingly, in the eastern North Atlantic the same order of magnitude of $S$ trends has been found in the Mediterranean outflow waters ( $S$ increase of $0.0028 \mathrm{yr}^{-1}$ over the period 1955-1993) by Potter and Lozier (2004). It is still controversial whether this increase is caused by changes in the North Atlantic Central Water (NACW) or by actual changes in the source waters within the Mediterranean (Potter and Lozier, 2004).

In the WMED the steady increase of the surface layer temperature close to the Catalan coast has been documented through a 30-yr long time series of fortnightly observations: $0.04{ }^{\circ} \mathrm{C} \mathrm{yr}^{-1}$ at the surface and $0.025^{\circ} \mathrm{C} \mathrm{yr}^{-1}$ at $80 \mathrm{~m}$ depth (Pascual et al., 1995; CIESM, 2002). Long-term $\theta$ and $S$ increases have been documented for the WMDW and for the LIW. In the deep layers these increases have been documented by various authors and for different periods: $0.0016^{\circ} \mathrm{C} \mathrm{yr}^{-1} / 0.0008 \mathrm{yr}^{-1}$ (1960-1995, Krahmann and Schott, 1998), $0.0027^{\circ} \mathrm{C} \mathrm{yr}^{-1} / 0.0019 \mathrm{yr}^{-1}$ (1969-1987, Leaman and Schott, 1991), $0.0035^{\circ} \mathrm{C} \mathrm{yr}^{-1} / 0.0011 \mathrm{yr}^{-1}$ (1957-1997, Béthoux et al., 1998), respectively for $\theta$ and $S$, to cite a few. Even stronger increases have been found in the Tyrrhenian Deep Water (TDW) by Fuda et al. (2002) $\left(0.016^{\circ} \mathrm{C} \mathrm{yr}^{-1}\right.$ and $0.008 \mathrm{yr}^{-1}$ during the $1990 \mathrm{~s}$, for $\theta$ and $S$ respectively). In the Ligurian subbasin in the layer occupied by the LIW core (300-400 m), Béthoux and Gentili (1996) detected a $\theta$ increase of $\sim 0.0068^{\circ} \mathrm{C} \mathrm{yr}^{-1}$ and a $S$ increase of $\sim 0.0018 \mathrm{yr}^{-1}$ (1960-1992), the latter being in accordance with the estimates for the EMED by Rohling and Bryden (1992) mentioned above. More recently, Millot et al. (2006) described a warming and salinification of the Mediterranean outflow waters, which in early 2000s were $0.3^{\circ} \mathrm{C}$ warmer and 0.06 saltier than in early 1980 s. Finally, since 2005 the deep waters of the WMED have experienced significant physical changes, which are comparable to the EMT, both in terms of intensity and observed effects (Schroeder et al., 2008). The production of high volumes of anomalously warm and salty new deep water during the winters 2004/2005 and 2005/2006 uplifted the old
Table 1. List of acronyms used in the paper.

\begin{tabular}{|c|c|}
\hline Acronym & Meaning \\
\hline AdDW & Adriatic Deep Water \\
\hline ANTARES & $\begin{array}{l}\text { Astronomy with a Neutrino Telescope and } \\
\text { Abyss environmental RESearch }\end{array}$ \\
\hline AW & Atlantic Water \\
\hline CAS & Camarinal Sill \\
\hline $\mathrm{CC}$ & Corsica Channel \\
\hline $\mathrm{CCC}$ & Cap de Creus Canyon \\
\hline CDW & Cretan Deep Water \\
\hline CS & Catalan slope \\
\hline $\mathrm{CT}$ & Conductivity-Temperature \\
\hline CTD & Conductivity-Temperature-Depth \\
\hline DWF & Dense Water Formation \\
\hline DYFAMED & $\begin{array}{l}\text { Dynamique des Flux Atmosphériques } \\
\text { en Mediterranée }\end{array}$ \\
\hline EMDW & Eastern Mediterranean Deep Water \\
\hline EMED & Eastern Mediterranean \\
\hline EMT & Eastern Mediterranean Transient \\
\hline EOW & Eastern Mediterranean Overflow Water \\
\hline ES & Espartel Sill \\
\hline GOL & Gulf of Lion \\
\hline $\mathrm{HC}$ & HYDROCHANGES \\
\hline JGOFS & Joint Global Ocean Flux Study \\
\hline LIW & Levantine Intermediate Water \\
\hline MBT & Mechanical Bathythermograph \\
\hline MEDAR/MEDATLAS & Mediterranean Data Archaeology and Rescue \\
\hline MedARGO & Mediterranean ARGO program \\
\hline MOW & Mediterranean Outflow Water \\
\hline MS & Moroccan Shelf \\
\hline MW & Mediterranean Waters \\
\hline NACW & North Atlantic Central Waters \\
\hline NAdDW & North Adriatic Dense Water \\
\hline$S$ & Salinity \\
\hline SBE & Sea-Bird Electronics \\
\hline $\mathrm{SC}$ & Sardinia Channel \\
\hline TDW & Tyrrhenian Deep Water \\
\hline TMW & Transitional Mediterranean Waters \\
\hline WMED & Western Mediterranean \\
\hline XBT & Expendable Bathythermograph \\
\hline$\theta$ & Potential Temperature \\
\hline
\end{tabular}

WMDW by several hundreds of meters in almost the whole western basin, inducing an abrupt increase in the deep heat and salt contents, thus resulting in a change in the deep stratification. The described changes were proposed by the group of researchers gathered at the CIESM workshop no. 38 to be referred to as the Western Mediterranean Transition (WMT), in order to avoid confusion with the better known EMT (CIESM, 2009). Data collected between 2004 and 2006 showed that in this period the deep layer of the WMED experienced a $\theta$ increase of $\sim 0.038^{\circ} \mathrm{C}$ and a $S$ increase of $\sim 0.016$ (Schroeder et al., 2008). These increases are five to seven times greater than the increasing trends indicated by Béthoux and Gentili (1999) and about four times greater than the estimates given for the 1985-2000 period by Rixen et al. (2005). These figures highlight the importance and the exceptional character of the 2004/2005 and 2005/2006 events, but also show how interannual variability can induce $\theta-S$ changes several times stronger than those associated to longterm changes. 
This fact reinforces the necessity of obtaining long-term series.

In general it is postulated that the majority of these changes and trends should be attributed to changes in the hydrological cycle and air-sea fluxes, and/or to the reduced river runoff as a consequence of human intervention (Leamann and Schott, 1991; Rohling and Bryden, 1992; Krahmann and Schott, 1998; Send et al., 1999; CIESM, 2009). Further, up to the early 2000s, the hypotheses about the causes of trends in the MWs were based on the assumption that the AW inflow at Gibraltar was not undergoing any properties change, and trends were attributed only to climatic and anthropogenic influences inside the Mediterranean Sea. Even if Krahmann and Schott (1998) reported a $S$ increase of the upper layer in the northern WMED, they attributed it to "local" causes (decrease of precipitations and river runoff), rather than to "upstream" changes (in the Atlantic and at Gibraltar). But the salinification of the AW inflow (see Sect. 3.1) observed thanks to HC data suggests that both causes need to be explored jointly (Millot, 2007). Indeed, the monitoring of the characteristics of the inflowing AW, which strongly modulates the Mediterranean circulation and DWF processes, should be included in any observational network, but both dynamical and topographic limitations make the long-term monitoring in this area a difficult task.

\subsection{Issues about monitoring hydrological variability}

Most of the past studies about hydrological variability rely on ship-based CTD or even bottle sample observations being operated only in specific places and on a monthly (at best) to annual basis. The data available since the beginning of the last century (e.g. Painter and Tsimplis, 2003) revealed that the sea has witnessed interannual and decadal variability as well as abrupt changes. Different timescales were thus involved in those processes. In the light of the above mentioned changes and trends, it is clear that the Mediterranean Sea is a highly sensitive, fast-reacting system. Indeed, the whole Mediterranean region has been defined as a "hot-spot" for climate change (Giorgi, 2006), as numerical model projections (2080-2099 minus 1960-1979) indicate pronounced mean warming (surface air temperature), large decrease in precipitation, and increase in precipitation variability during the dry (warm) season. This is another reason why it is of much interest to study the evolution of water masses in this region in response to such climatic changes, as well as to improve knowledge about the general functioning of the sea, its internal feedback mechanisms and specific processes.

The coexistence of different temporal and spatial scales in the ocean-atmosphere system makes it difficult to analyse oceanographic time series and to detect trends, since the number of long oceanic instrumental time series is much smaller and scattered in time and space than for meteorological observations. Long time series are practically lim- ited to tide gauge data. In general, the lack of long-term records precludes a more profound knowledge of the marine response to the climatic forcings. Oceanographic trends are thus usually estimated by using CTD data, which are highly scattered in time and space. This implies that the resulting trend estimates can be very different, depending on the period considered (i.e. the first and the last point in a time series), the place, the depth interval used and so on. Further limitations in the use of time- and space-scattered (shiphandled CTD) data for trends estimates are: (i) the sensitivity of results to data analysis methods in the case of scarce data sets (Vargas-Yáñez et al., 2009); (ii) difficulty in detecting trends in shallow waters or in the surface layer, where short term variability is high and seasonal cycles are difficult to remove (Vargas-Yáñez et al., 2009); (iii) difficulty to properly estimate important statistical parameters, such as data significance and covariance between data sets, due to large gaps in time series; (iv) difficulty in comparing trends estimated in different places and/or different periods (Millot et al., 2006), preventing an analysis of propagation of signals through the sea (in terms of phase lags between time series); (v) high expensiveness of the experimental strategy, in terms of costs and logistics, preventing the measurements to be performed on e.g. a weekly basis, except for coastal regions (Pascual et al., 1995); (vi) instrumental biases in temperature time series (Vargas-Yáñez et al., 2010). Feedback mechanisms regulating the connections between climate, circulation and marine ecosystems, and possible alterations under future climate scenarios are not yet well understood. In addition, several Mediterranean areas, mainly its southern parts, are widely undersampled (and some of them have never been sampled), due to historical-political difficulties, as well as to financial and logistic constraints. This is a serious limit, given the importance of intense mesoscale dynamics in these areas, which makes the interpretation of data from monitoring programs even more difficult (Millot and Briand, 2002), and prevents reliable trend detection from episodic and sparse observations (e.g. Millot and Taupier-Letage, 2005).

Even though the task of investigating the long-term variability of hydrological properties by using shipboard CTD data was greatly aided by an EU coordinated action, MEDAR-MEDATLAS (Mediterranean Data Archaeology and Rescue), which managed to facilitate access to the dispersed CTD data sets together with data from bottles, expendable bathythermograph (XBT) and mechanical bathythermograph (MBT) probes and developed a joint comprehensive database of oceanographic data (1900-2002, Mediterranean and Black Sea) (MEDAR Group, 2002), this data set was basically not very suitable to specify long term variations (scarcity of data, high noise levels). Nevertheless these data provide useful information about long term changes in the past, some of them have been enumerated above and can be summarised as the warming and salinification of deep waters and the salinity increase of intermediate waters both in the eastern and western Mediterranean. 


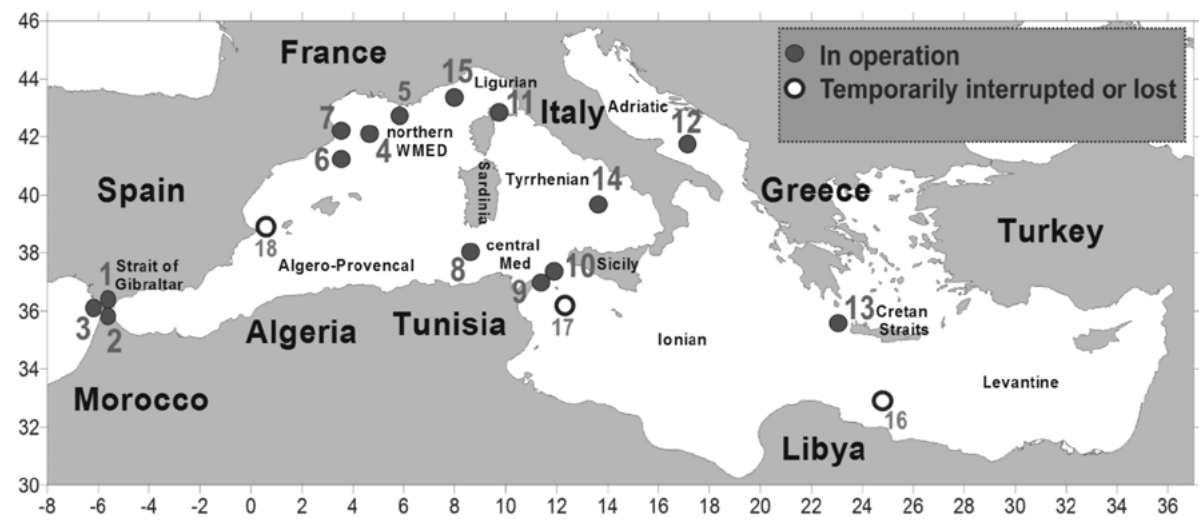

Fig. 1. Present status of the HYDROCHANGES network. The numbers refer to details of each site, which are listed in Table 2: involved institutes, position, time frame, instruments and measured parameters for each depth.

\section{Data and methods}

The limitations listed in paragraph 1.2 were the main reason for the proposal of a CIESM coordinated workshop in 2002 (CIESM workshop no. 6, Monaco, April 2002) entitled "Tracking long-term hydrological change in the Mediterranean" (CIESM, 2002). During the workshop, more than 30 scientists from 12 countries found a general agreement that the monitoring of hydrological long-term variability needed a coordinated action having a twofold objective, i.e. to better specify trends in different regions all over the sea and to better understand the major processes of the sea functioning. In the definition of a common strategy some priorities had to be defined, since a regular monitoring of the climate system cannot be applied to all temporal and spatial scales over the whole Mediterranean, and not all parameters can be monitored. The adopted HC strategy has been the continuous monitoring of key sites. It has been recognized that permanently collecting time series at some specific places, even if in a relatively limited number, was the sole strategy that clearly would allow comparisons and thus inferences about the propagation of signals, the circulation and the functioning of the sea.

$\mathrm{HC}$ has become over the years one of the emblematic CIESM programmes, as it well reflects key characteristics of the Commission's engagement: limited but guaranteed funding over a long-term horizon, donation and maintenance of material (CTDs in this case) provided to developing Mediterranean countries, north-south cooperation with continuous capacity building (training of local engineers and physicists), cross-basin scale with a gradual but sure extension of the network towards eastern and southern waters, in-depth discussion of HC at each CIESM Congress, etc.

With the focus on trend detection, the HC coordinated action is thus aimed at (i) addressing problems on the long term (i.e. the action should continue over decades), (ii) focusing on temporal variability, using eulerian data at few selected key locations and from the surface layer down to the greatest depths, (iii) achieving the necessary time and space resolutions (i.e. to resolve all important variations, at least in time), which requires autonomous instrumentation collecting data at high temporal resolution over decades in as many places as possible (a sort of sea-wide experiment), (iv) using instrumentations as inexpensive and simple as possible (CIESM, 2002). The strength of this type of measurements, which complement other existing components of the global ocean observing system (e.g., ARGO, gliders, satellites, ship-based hydrology, XBTs, integrated coastal observing systems) are the high temporal resolution (which allows to resolve events and abrupt variations and processes), the possibility to make measurements in locations that otherwise would be difficult to perform with mobile platforms (such as straits and boundary currents), and the maintenance of a long-term presence in those sites, since sustained eulerian long time series are considered the most powerful tool for the identification of climate change effects (Send et al., 2010).

\subsection{Present status and monitored sites}

At present day, nine years after the beginning of the programme, the $\mathrm{HC}$ network involves up to 15 fully operational mooring sites, three temporarily interrupted or lost moorings and one foreseen in the Algerian subbasin. The list includes two new sites that have joined the HC network in summer 2010. There are 12 involved institutes from six countries around the Mediterranean Sea. The synthesis of the present network status is given in Table 2 and Fig. 1. As can be seen from Table 2, some regions have been monitored, without interruption, well before the start of the HC programme. Soon after the initial CIESM workshop of 2002, the first two moorings under the $\mathrm{HC}$ umbrella were deployed at Gibraltar to monitor the inflowing and outflowing water masses (January 2003) in the framework of a collaboration between the Service Hydrographique et Océanographique de la Marine Royale du Maroc (SHOMAR) and the French CNRS Centre d'Océanologie de Marseille (CNRS/COM). Shortly 
Table 2. Contributing institutes and details of the monitored sites.

\begin{tabular}{|c|c|c|c|c|c|}
\hline ID & $\begin{array}{l}\text { Institute/Group (country)/ } \\
\text { Point of contact }\end{array}$ & $\begin{array}{l}\text { Site (lon, lat) } \\
\text { Acronym used in figures }\end{array}$ & Period & $\begin{array}{l}\text { Bottom depth/ } \\
\text { mooring length }\end{array}$ & $\begin{array}{l}\text { Installed instruments (depth) - } \\
\text { measured parameters } \\
(* \text { indicates which data are } \\
\text { plotted in figures })\end{array}$ \\
\hline 1 & $\begin{array}{l}\text { SHOMAR\&CNRS/COM (Morocco, France)/ } \\
\text { Bouchta El Moumni, Lahoucine Bengara, } \\
\text { Gilles Rougier, Isabelle Taupier-Letage }\end{array}$ & $\begin{array}{l}\text { Camarinal Sill - Gibraltar, } \\
\left(35^{\circ} 55.2^{\prime} \mathrm{N}, 5^{\circ} 44.9^{\prime} \mathrm{W}\right) \text { CAS }\end{array}$ & $\begin{array}{l}\text { Jan 2003- } \\
\text { present }\end{array}$ & $270 \mathrm{~m} / 10 \mathrm{~m}$ & $\begin{array}{l}\text { *SBE37 }(270 \mathrm{~m}) \text { - temperature, } \\
\text { conductivity }\end{array}$ \\
\hline 2 & $\begin{array}{l}\text { SHOMAR\&CNRS/COM (Morocco, France)/ } \\
\text { Bouchta El Moumni, Lahoucine Bengara, } \\
\text { Gilles Rougier, Isabelle Taupier-Letage }\end{array}$ & $\begin{array}{l}\text { Moroccan shelf - Gibraltar } \\
\left(35^{\circ} 52.9 \mathrm{~N}, 5^{\circ} 43.6^{\prime} \mathrm{W}\right) \mathrm{MS}\end{array}$ & $\begin{array}{l}\text { Jan } 2003- \\
\text { Oct } 2008\end{array}$ & $\begin{array}{l}80 \mathrm{~m} / 10 \mathrm{~m} \\
\text { conductivity }\end{array}$ & *SBE37 $(80 \mathrm{~m})$ - temperature, \\
\hline 3 & $\begin{array}{l}\text { University of Malaga, UMA (Spain)/ } \\
\text { Jesus García-Lafuente }\end{array}$ & $\begin{array}{l}\text { Espartel Sill - Gibraltar } \\
\left(35^{\circ} 51.72^{\prime} \mathrm{N}, 5^{\circ} 58.59^{\prime} \mathrm{W}\right) \mathrm{ES}\end{array}$ & $\begin{array}{l}\text { Oct 2004- } \\
\text { March } 2011\end{array}$ & $360 \mathrm{~m} / 15 \mathrm{~m}$ & $\begin{array}{l}\text { ADCP RDI LR }(345 \mathrm{~m}) \text { - current profile } \\
\text { NORTEK Aquadopp }(352 \mathrm{~m}) \text { - current } \\
\text { *SBE37 }(356 \mathrm{~m}) \text { - conductivity, temperature }\end{array}$ \\
\hline 4 & $\begin{array}{l}\text { CNRS/COM (France)/Gilles Rougier, } \\
\text { Isabelle Taupier-Letage }\end{array}$ & $\begin{array}{l}\text { Gulf of Lion } \\
\left(41^{\circ} 59.0^{\prime} \mathrm{N}, 04^{\circ} 55^{\prime} \mathrm{E}\right) \mathrm{GoL}\end{array}$ & $\begin{array}{l}\text { Oct 2006- } \\
\text { present }\end{array}$ & $2400 \mathrm{~m} / 10 \mathrm{~m}$ & $\begin{array}{l}\text { *SBE37 }(2400 \mathrm{~m})-\text { temperature, conductivity MORS } \\
\text { currentmeter }(2400 \mathrm{~m}) \text { - current }\end{array}$ \\
\hline 5 & $\begin{array}{l}\text { ANTARES Group (France)/Christian } \\
\text { Tamburini, Dominque Levefre }\end{array}$ & $\begin{array}{l}\text { Offshore Toulon } \\
\left(42^{\circ} 45^{\prime} \mathrm{N}, 6^{\circ} 10^{\prime} \mathrm{E}\right) \text { ANTARES }\end{array}$ & $\begin{array}{l}\text { Dec 2007- } \\
\text { present }\end{array}$ & $2500 \mathrm{~m} / 350 \mathrm{~m}$ & $\begin{array}{l}\text { *SBE37 }(2200 \mathrm{~m}) \text { - temperature, conductivity } \\
\text { SBE37 }(2290 \mathrm{~m}) \text { - temperature, conductivity } \\
\text { RCM8 }(2300 \mathrm{~m}) \text { - current, temperature, conductivity } \\
\text { ADCP }(2400 \mathrm{~m}) \text { - current profile }\end{array}$ \\
\hline 6 & $\begin{array}{l}\text { ICM-CSIC (Spain)/ Jordi Font, } \\
\text { Pere Puig, Jordi Salat }\end{array}$ & $\begin{array}{l}\text { Catalan Slope } \\
\left(41^{\circ} 28.0^{\prime} \mathrm{N}, 03^{\circ} 40.4^{\prime} \mathrm{E}\right) \mathrm{CS}\end{array}$ & $\begin{array}{l}\text { Oct 2003- } \\
\text { present }\end{array}$ & $1890 \mathrm{~m} / 30 \mathrm{~m}$ & $\begin{array}{l}\text { *SBE } 37(1875 \mathrm{~m}) \text { - temperature, conductivity } \\
\text { RCM8 }(1878 \mathrm{~m}) \text { - current, temperature, conductivity } \\
\text { RCM11 }(1881 \mathrm{~m}) \text { - current, temperature, conductivity }\end{array}$ \\
\hline 7 & $\begin{array}{l}\text { ICM-CSIC (Spain)/ } \\
\text { Pere Puig }\end{array}$ & $\begin{array}{l}\text { Cap de Creus Canyon } \\
\left(42^{\circ} 23.4^{\prime} \mathrm{N}, 3^{\circ} 19.3^{\prime} \mathrm{E}\right) \mathrm{CCC}\end{array}$ & $\begin{array}{l}\text { Nov 2003- } \\
\text { present }\end{array}$ & $315 \mathrm{~m} / 15 \mathrm{~m}$ & $\begin{array}{l}\text { *RCM } 9(310 \mathrm{~m})-\text { current, temperature, } \\
\text { conductivity, turbidity }\end{array}$ \\
\hline 8 & $\begin{array}{l}\text { INSTM\&CNRS/COM (Tunisia, France)/ } \\
\text { Cherif Sammari, Ben Ismail (2012) }\end{array}$ & $\begin{array}{l}\text { Sardinian Channel } \\
\left(38^{\circ} 20.047^{\prime} \mathrm{N}, 09^{\circ} 19.959^{\prime} \mathrm{E}\right) \mathrm{SC}\end{array}$ & $\begin{array}{l}\text { Jul 2003- } \\
\text { present }\end{array}$ & $1900 \mathrm{~m} / 10 \mathrm{~m}$ & $\begin{array}{l}\text { *SBE37 }(1900 \mathrm{~m}) \text { - temperature, conductivity } \\
\text { RCM8 }(1900 \mathrm{~m}) \text { - current, temperature, } \\
\text { conductivity }\end{array}$ \\
\hline 9 & $\begin{array}{l}\text { CNR-ISMAR (Italy)/ } \\
\text { Katrin Schroeder, Mireno Borghini }\end{array}$ & $\begin{array}{l}\text { Sicily Channel } \\
\left(37^{\circ} 17.120^{\prime} \mathrm{N}, 11^{\circ} 30.019^{\prime} \mathrm{E}\right) \mathrm{C} 02\end{array}$ & Since 1993 & $530 \mathrm{~m} / 273 \mathrm{~m}$ & $\begin{array}{l}\text { NORTEK Aquadopp }(400 \mathrm{~m}) \text { - current } \\
\text { SBE37 }(395 \mathrm{~m}) \text { - temperature, conductivity } \\
\text { RCM7 }(300 \mathrm{~m}) \text { - current, temperature, conductivity } \\
\text { ADCP NORTEK Continental }(250 \mathrm{~m}) \text { - current profile }\end{array}$ \\
\hline 10 & $\begin{array}{l}\text { CNR-ISMAR (Italy)/ } \\
\text { Katrin Schroeder, Mireno Borghini }\end{array}$ & $\begin{array}{l}\text { Sicily Channel } \\
\left(37^{\circ} 22.836^{\prime} \mathrm{N}, 11^{\circ} 35.636^{\prime} \mathrm{E}\right) \mathrm{C} 01\end{array}$ & Since 1993 & $450 \mathrm{~m} / 365 \mathrm{~m}$ & $\begin{array}{l}\text { ADCP RDI WH }(415 \mathrm{~m}) \text { - current profile } \\
\text { *SBE37 }(387 \mathrm{~m}) \text { - temperature, conductivity } \\
\text { SBE37(82 m) - temperature, conductivity }\end{array}$ \\
\hline 11 & $\begin{array}{l}\text { CNR-ISMAR (Italy)/Katrin Schroeder, } \\
\text { Mireno Borghini }\end{array}$ & $\begin{array}{l}\text { Corsica Channel } \\
\left(43^{\circ} 02.021^{\prime} \mathrm{N}, 9^{\circ} 41.154^{\prime} \mathrm{E}\right) \mathrm{CC}\end{array}$ & Since 1985 & $440 \mathrm{~m} / 370 \mathrm{~m}$ & $\begin{array}{l}\text { RCM7 }(410 \mathrm{~m}) \text { - current, temperature, conductivity } \\
\text { RCM9 }(320 \mathrm{~m}) \text { - current, temperature } \\
\text { *SBE37 }(400 \mathrm{~m}) \text { - temperature, conductivity } \\
\text { RCM9 }(70 \mathrm{~m}) \text { - current, temperature }\end{array}$ \\
\hline 12 & $\begin{array}{l}\text { OGS (Italy)/ } \\
\text { Vanessa Cardin }\end{array}$ & $\begin{array}{l}\text { Southern Adriatic } \\
\left(41^{\circ} 50^{\prime} \mathrm{N}, 17^{\circ} 45^{\prime} \mathrm{E}\right)\end{array}$ & $\begin{array}{l}\text { Nov 2006- } \\
\text { present }\end{array}$ & $1204 \mathrm{~m} / 840 \mathrm{~m}$ & $\begin{array}{l}\text { ADCP RDI BB (before: } 265 \mathrm{~m} / \text { after: } 360 \mathrm{~m}) \text { - current } \\
\text { *SBE19 }(364 \mathrm{~m}) \text { - temperature, conductivity, turbidity, oxygen } \\
\text { *SBE37 }(564 \mathrm{~m}) \text { - temperature, conductivity } \\
\text { *SBE19 }(764 \mathrm{~m}) \text { - temperature, conductivity, turbidity, oxygen } \\
\text { *SBE37 }(1014 \mathrm{~m}) \text { - temperature, conductivity } \\
\text { *SBE37 }(1172) \text { - temperature, conductivity } \\
\text { RCM11 }(1182 \mathrm{~m}) \text { - current, temperature, turbidity }\end{array}$ \\
\hline 13 & $\begin{array}{l}\text { HCMR (Greece)/ } \\
\text { Harilaos Kontoyiannis }\end{array}$ & $\begin{array}{l}\text { Antikythira Strait } \\
\left(35^{\circ} 36.6^{\prime} \mathrm{N}, 23^{\circ} 31.8^{\prime} \mathrm{E}\right)\end{array}$ & $\begin{array}{l}\text { Nov 2007-May } 2009 \& \\
\text { Jun 2010-Nov } 2010\end{array}$ & $870 \mathrm{~m} / 15 \mathrm{~m}$ & $\begin{array}{l}{ }^{*} \text { SBE } 37(850 \mathrm{~m}) \text { (temperature, } \\
\text { conductivity, pressure) }\end{array}$ \\
\hline 14 & $\begin{array}{l}\text { DiSAm, CNR-ISMAR, ENEA-UTMAR, } \\
\text { CONISMA (Italy)/ } \\
\text { Katrin Schroeder, Giorgio Budillon }\end{array}$ & $\begin{array}{l}\text { Central Tyrrhenian } \\
\left(39.4994^{\circ} \mathrm{N}, 13.4765^{\circ} \mathrm{E}\right) \text { present }\end{array}$ & Aug 2010-present & $\begin{array}{l}3410 \mathrm{~m} / 1650 \mathrm{~m} \\
\text { TYR }\end{array}$ & $\begin{array}{l}\text { *SBE37 }(3380 \mathrm{~m}) \text { - temperature, conductivity } \\
\text { RCM11 }(3370 \mathrm{~m}) \text { - current, temperature } \\
\text { *SBE39 }(2524) \text { - temperature } \\
\text { RCM7 }(1774 \mathrm{~m}) \text { - current, temperature, conductivity }\end{array}$ \\
\hline 15 & $\begin{array}{l}\text { Observatoire Oceanologique de } \\
\text { Villefranche-sur-mer (France)/Laurent Coppola }\end{array}$ & $\begin{array}{l}\text { Ligurian subbasin } \\
\left(43.4185^{\circ} \mathrm{N}, 7.903^{\circ} \mathrm{E}\right) \mathrm{DYF}\end{array}$ & $\begin{array}{l}\text { Jun 2009- } \\
\text { present }\end{array}$ & $2350 \mathrm{~m} / 2200 \mathrm{~m}$ & $\begin{array}{l}\text { SBE37 }(200 \mathrm{~m}) \text { - temperature, conductivity } \\
\text { *SBE37 }(700 \mathrm{~m}) \text { - temperature, conductivity } \\
\text { SBE37 }(1000 \mathrm{~m}) \text { - temperature, conductivity } \\
\text { *SBE37 }(2000 \mathrm{~m}) \text { - temperature, conductivity } \\
\text { RBR }(170 \mathrm{~m})-\text { temperature } \\
\text { RBR }(350 \mathrm{~m})-\text { temperature } \\
\text { RBR }(500 \mathrm{~m})-\text { temperature } \\
\text { Aquadopp }(200 \mathrm{~m}) \text { - current, temperature } \\
\text { Aquadopp }(1000 \mathrm{~m}) \text { - current, temperature }\end{array}$ \\
\hline 16 & $\begin{array}{l}\text { COM/LOB (France)/Gilles Rougier, } \\
\text { Isabelle Taupier-Letage }\end{array}$ & $\begin{array}{l}\text { South-western Levantine } \\
\left(32.2967^{\circ} \mathrm{N}, 25.6018^{\circ} \mathrm{E}\right)\end{array}$ & $\begin{array}{l}\text { April 2006- } \\
\text { March } 2007\end{array}$ & $3226 \mathrm{~m}$ & \\
\hline 17 & INSTM\&CNRS/COM (Tunisia, France) & Central Sicily Channel & & & \\
\hline 18 & IEO (Spain) & Ibiza Channel & & & \\
\hline
\end{tabular}

after, in July 2003, the Tunisian Institut National des Sciences et Technologies de la Mer (INSTM), with the support of CNRS/COM staff, deployed two deep moorings, in the Sardinia Channel at $1900 \mathrm{~m}$ as well as in the central part of the Sicily Channel at $1200 \mathrm{~m}$ depth (now lost), to monitor the exchanges between the two Mediterranean basins. In the same year (October-November 2003) the DWF area in the northern WMED started to be monitored with a mooring on the lower part of the Catalan slope (at $1890 \mathrm{~m}$ ) and another one (at $315 \mathrm{~m}$ ) in the upper part of the Cap de Creus Canyon, by the Spanish Institut de Ciències del Mar (ICM-CSIC). A third mooring at Gibraltar was deployed 
further west (Espartel Sill) in October 2004 by the University of Malaga (UMA), to monitor the variability of the outflowing MWs in the main channel of this section (at $360 \mathrm{~m}$ ). The CNRS/COM also initiated a monitoring site in the Gulf of Lion in October 2006, which is providing complementary results to the ICM-CSIC data. The importance of this DWF region is evidenced by the fact that a third mooring has started operating there in December 2007; through its collaboration with CNRS/COM, the ANTARES (Astronomy with a Neutrino Telescope and Abyss environmental RESearch, see ANTARES Collaboration, 2006) collaboration participates in the CIESM HC programme. Most of the HC monitoring sites are located in the WMED. Presently in the EMED, the Italian Istituto Nazionale di Oceanografia e di Geofisica Sperimentale (OGS) operates a mooring site in the southern Adriatic, a DWF region as well, since 2002 (continuously since November 2006), while the Greek Hellenic Centre for Marine Research (HCMR) deployed a mooring in the Antikithira Strait in November 2007. A one-year time series was recorded off Libya, in the southwestern Levantine subbasin (3226 m depth) from April 2006 to March 2007 by CNRS/COM (Taupier-Letage et al., 2007). Recently (summer 2010), two more mooring sites joined the HC network: one in the Ligurian subbasin $(2350 \mathrm{~m}$, close to the DYFAMED site), managed by the French Observatoire Oceanologique de Villefranche-sur-mer, and one in the central deep Tyrrhenian $(3410 \mathrm{~m})$, a region where the water of eastern origin cascades to great depths and contributes to the formation of the TDW. This latter mooring is managed jointly by the Italian groups at DiSAm (Department of Environmental Sciences of the "Parthenope" University of Naples), CNR-ISMAR, and ENEA-UTMAR (Technical Unit for Marine Environment and Sustainable Development of the Italian National Agency for New Technologies, Energy and Sustainable Economic Development).

Presently (Fig. 1 and Table 2) there is good spatial coverage of key regions, especially in the WMED, while only two site are fully operational in the EMED. Besides this E-W imbalance, there are other key regions that should be included in the network, in order to be more representative and useful for the description of the sea functioning and the understanding of its long-term variability. Those issues are detailed in Sect. 5 and represent future commitments for the $\mathrm{HC}$ community.

\subsection{Instruments and data processing}

The basic HC strategy is to employ relatively inexpensive, autonomous instruments, which are highly performing in terms of accuracy, resolution, stability, memory and energy consumption, to constitute a network of autonomous oceanographic stations with a wide geographical coverage of the Mediterranean Sea (CIESM, 2002), placing CTDs in key regions, on short and easily manageable subsurface moorings. Ship-based CTDs are still necessary to provide information on the spatial distribution of temperatures and salinities in the moorings' surroundings. Since $\mathrm{HC}$ aims at evidencing trends that are of the order of $O(0.001-0.01)$ per year, the greatest care must be taken for $\theta$ (and $S$ ) measurements. Therefore the $\mathrm{HC}$ quality requirement is to employ SBE37 MicroCATs manufactured by Sea-Bird Electronics (Bellevue, Washington, USA; www.seabird.com/products/spec_sheets/ 37sidata.htm) to measure temperature, conductivity and (optional) pressure (Table 2). The SBE37 MicroCAT is a highaccuracy temperature and conductivity sensor, very stable in time, with an optional pressure gauge. A pressure gauge is very important for the accurate determination of hydrological long-term variability. For instance, for the computation of salinity a pressure difference of $10 \mathrm{dbar}$ (which is of the order of the uncertainty about the actual immersion of moorings, especially on varying bathymetry) may cause a salinity difference of $\sim 0.004$. Constructed of titanium and other noncorroding materials to ensure long life with minimum maintenance, the MicroCAT's depth capability is $7000 \mathrm{~m}$. The MicroCAT's unique internal-field conductivity cell permits the use of expendable anti-foulant devices, which is of the utmost importance to guarantee the good quality of conductivity data especially for shallow moorings. The aged and pressure-protected thermistor has a long history of exceptional accuracy and stability.

The accuracy of the MicroCAT is sustained by the care and periodic calibration of the sensors and by establishing proper handling practices, respecting the manufacturer's recommendations. The primary source of temperature sensor drift is the aging of the thermistor element. Sensor drift will usually be a few thousandths of a degree during the first year, and less in subsequent intervals. Sensor drift is not substantially dependent upon the environmental conditions, and the thermistor is insensitive to shock. All sensors are calibrated by the manufacturer, coefficients are then computed, which are used with appropriate algorithms to obtain engineering units. The conductivity and temperature sensors on the MicroCAT are supplied fully calibrated. Each HC partner is then responsible for the successive calibrations, ideally on a yearly basis (or less, if maintenance is more frequent). Recalibrations are made either in at home calibration baths or returning the sensor regularly to the manufacturer. The new calibration coefficients are then applied to the time series between two successive calibrations. Even though there is not a common data format established between the partners, all data are processed following common recognized post-processing QA/QC procedures, which make them extremely reliable. Furthermore, flags are assigned according to domain criteria specified for each parameter as well as by visual inspection of data values and scatter/line plots.

The data that are presented in the following section have not been time-averaged. The original acquisition frequency (ranging from 15 minutes to $1 \mathrm{~h}$, depending on the site) has been used for representing the time series. 


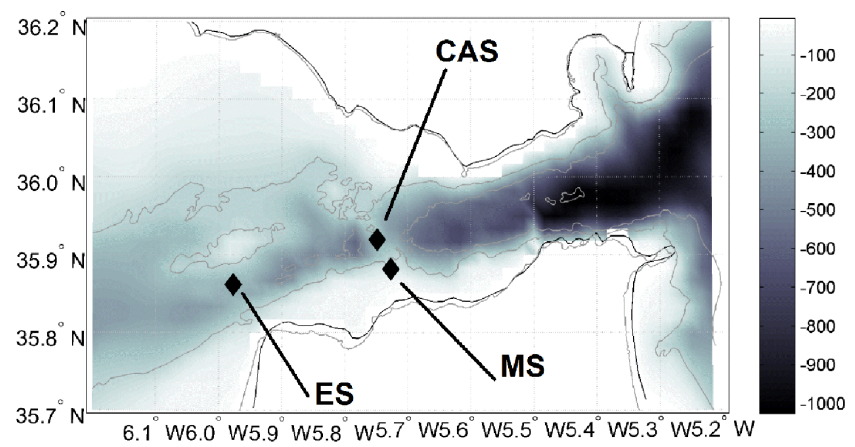

Fig. 2. Location of the three monitoring sites at Gibraltar $(\mathrm{ES}=$ Espartel Sill; CAS = Camarinal Sill; $\mathrm{MS}=$ Moroccan Shelf $)$.

\section{Results}

Key regions presently monitored in the HC framework include straits, channels, DWF areas, the deeper parts of various subbasins and the continental rise. In this section we provide an overview of all $\mathrm{HC} \theta$ time series collected in different parts and depths of the Mediterranean Sea, generally in the core of a certain water mass. In all cases the temporal resolution of the records, spanning from minutes to a few hours, is well suited to resolve the scales of variability of concern here (long-term, interannual variability) The presentation is mainly devoted to $\theta$ ( $S$ is not shown, with the exception of the AW at Gibraltar), as not all sites have post-calibrated $S$ data yet (and pressure data, allowing an accurate computation of salinity from conductivity data are not available for all sites).

At each mooring site the partners have deployed autonomous CTDs, often accompanied by current meters (Table 2). The relevant amount of data has been in part exploited scientifically, also linking them with repeated CTD sections (Gasparini et al., 2005; Vargas-Yáñez et al., 2005, 2009, 2010; Millot et al., 2006; Millot, 2007, 2009; Palanques et al., 2006, 2009, 2012; García-Lafuente et al., 2007, 2009, 2011; Font et al., 2007; CIESM, 2008, 2009; Puig et al., 2008, 2013; Sánchez-Román et al., 2009; Millot and García-Lafuente, 2011; Ribó et al., 2011). There are evidences of interannual $\theta$ and $S$ variability in different water masses, even though most of the HC time series are still too short to significantly address issues on long-term variability and trends. Nevertheless, the results are encouraging and are providing new insights on the functioning of the sea. Observations collected till now in each site are described in the following, while an attempt to link different time series is done in Sect. 4.

\subsection{The Strait of Gibraltar}

Deploying and maintaining long-term moorings in this region, "the key-place" to monitor the overall functioning of the Mediterranean Sea, presents some specific difficulties, due to the complex topography, the bio-fouling, the presence of strong tidal currents that reverse the inflow and/or the outflow in many places of the strait (Candela et al., 1990; Bryden et al., 1994; García-Lafuente et al., 2000), as well as the remarkable internal tide that strongly distorts what is basically a two-layer exchange, through mixing processes often reaching the bottom in the whole strait.

As already discussed, the inflowing AW directly conditions the properties of the water masses involved in the Mediterranean Sea circulation (MW), in DWF processes and finally in the Mediterranean Outflow Waters (MOW). Monitoring AW should therefore be considered a necessity for all analyses dealing with trends in the sea and thus be included in any observational network (Millot and Briand, 2002). This is why the first HC mooring was deployed in 2003 at $80 \mathrm{~m}$ on the Moroccan Shelf (MS, Fig. 2), a convenient place due to an AW-MOW interface generally sloping down southward.

To monitor MOWs, two favourable sites are the Camarinal and Espartel sills (CAS and ES in Fig. 2), which have advantages for the monitoring purpose and display some similarities (García-Lafuente et al., 2007). Bray et al. (1995) showed that the greatest AW vs. MOWs contrast is at CAS, which points at this sill as the best place for monitoring the twolayer exchange. On the other hand, experimental (Farmer and Armi, 1988; Sánchez-Román et al., 2009) and numerical (Castro et al., 2004; Sannino et al., 2004, 2009; SánchezRomán et al., 2009) studies suggest that hydraulic control on MOW is a rather permanent feature at ES, which is the last topographic constriction before they sink in the ocean down to $\sim 1000 \mathrm{~m}$ (Baringer and Price, 1997; Ambar et al., 2002), while at CAS the hydraulic control is lost almost every tidal cycle. This hydraulic behaviour gives ES practical advantages to compute the volume transport using a single mooring line. Thus, HC moorings were deployed at both sites, near the southern sill at CAS on a small plateau at $270 \mathrm{~m}$ (since its deepest part at $290 \mathrm{~m}$ is steeply V-shaped), and at the southern sill at ES $(350 \mathrm{~m})$. However, it must be emphasized that the MOW outflowing in the northern part of the strait are totally missed (Millot, 2013).

For AW, Fig. 3 (adapted from Millot, 2007) shows a marked seasonal variability of $S$ (amplitude $\sim 0.5$, maximum in winter), due to air-sea interactions, and a remarkable interannual salinification during 2003-2007 (about $\sim 0.05 \mathrm{yr}^{-1}$, according to Millot, 2007). This fact reflects (according to Millot, 2007) the marked variability evidenced in the nearby ocean (e.g. Reverdin et al., 2007) and cannot be extrapolated to the evolution of AW in the long-term. Since it was observed at the very beginning of the $\mathrm{HC}$ experiment, it clearly validates the HC strategy and questions (as expected by Millot and Briand, 2002) bulk analyses that, more or less explicitly, assume a constant salt content within the sea (e.g. Béthoux et al., 1998; Rohling and Bryden, 1992).

The MOW seasonality in the strait is still a debated question. Some authors (e.g. García-Lafuente et al., 2007) claim that the MOW leaving the sea is relatively warm and light 


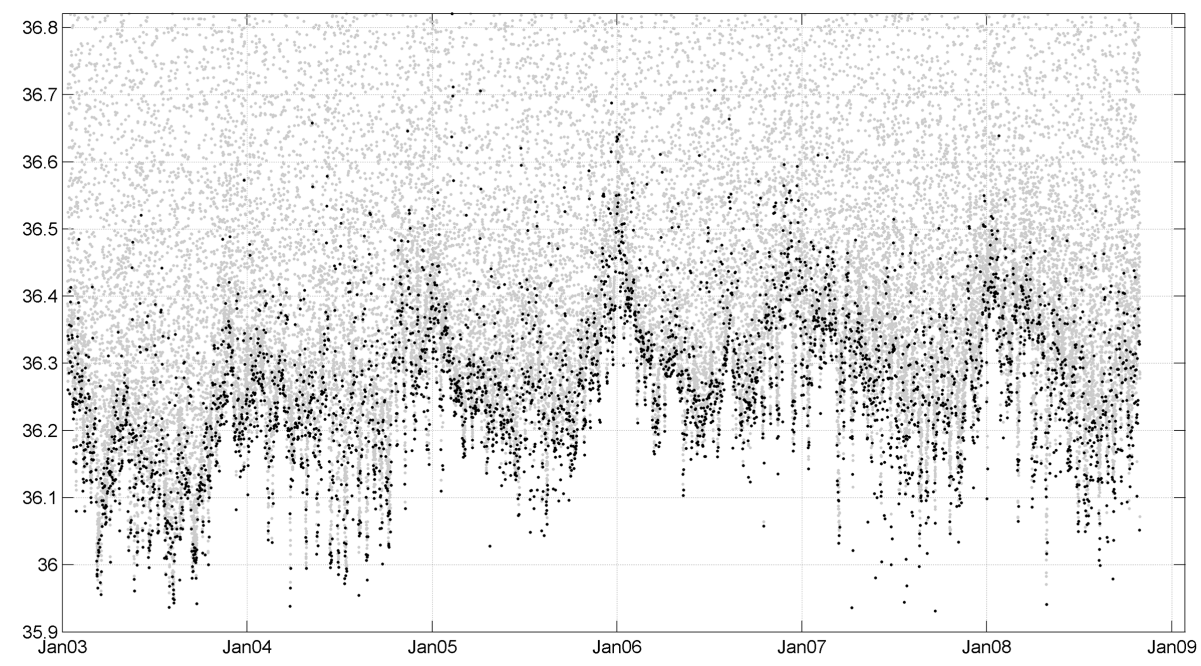

Fig. 3. $S$ time series of the AW (at $80 \mathrm{~m}$ ) on the MS (west of Gibraltar). The black dots represent the lowest $S$ value during each semi-diurnal $(12 \mathrm{~h})$ cycle.

in early winter and cooler and dense in late spring and summer, with amplitudes of $0.05^{\circ} \mathrm{C}$ and $0.015 \mathrm{~kg} \mathrm{~m}^{-3}$ for $\theta$ and potential density, respectively. The $\theta$ minimum, occurring usually in April, is also accompanied by a MOW maximum transport. On the contrary, Millot (2009) assumes that the MOW entering the strait does not display any significant seasonality until it starts mixing with AW. Whatever the case, Millot and García-Lafuente (2011) showed that tidal mixing with the seasonally variable AW within the strait induces seasonal and fortnightly variability in the MOW. Millot et al. (2006) showed that in the early 2000s the MWs at CAS was $\sim 0.3{ }^{\circ} \mathrm{C}$ warmer and $\sim 0.06$ saltier than in the $1980 \mathrm{~s}$ and earlier. They hypothesized that this was due to changes in the MOW composition, with waters originated in the eastern basin representing, in the early 2000s, higher percentages than those originated in the western basin, maybe as a consequence of the EMT. At CAS, this mainly results in sampling TDW more often than WMDW. A different explanation was given by García-Lafuente et al. $(2007,2009)$ who suggest that the observed variability derives from the different properties of the dense waters located at the maximum depth from where they can be uplifted and aspired through the strait. That depth is roughly located in the transitional layer between LIW and WMDW in the Alboran subbasin (Parrilla et al., 1986; Kinder and Bryden, 1990), so that any vertical displacements of this layer would change the $\theta-S$ characteristics of the aspired water. This explanation emphasizes another debated feature since Millot (2009) questions the necessity to invoke any aspiration process. Indeed, when the newly formed, relatively dense WMDW sinks to the bottom, it uplifts all other waters in the western basin: should WMDW be the sole water in such a basin, the oldest WMDW would thus be naturally uplifted, year after year, up to the sill at CAS.
García-Lafuente et al. (2007) showed a rather similar behaviour of $\theta$ at CAS and ES with a correlation coefficient of 0.94 and a quite constant difference of $0.107 \pm 0.021^{\circ} \mathrm{C}$ (see Fig. 4), indicating similar fluctuations ranges for tidefiltered data at both sills. The similarity is striking in March 2005 and February 2006, when the same sharp $\theta$ decrease is registered simultaneously at both sills. Further, MOW at ES is fresher (not shown) and warmer (Fig. 4) than at CAS, due to the progressive mixing in the Tangier Basin with either NACW (García-Lafuente et al., 2011) or Surface Atlantic Water (SAW) (Millot, 2013). It is now demonstrated (Millot and García-Lafuente, 2011) that AW-MOW mixing lines $(\mathrm{d} \theta / \mathrm{d} S)$ inferred from the tide-filtered time series generally show similar slopes at both CAS and ES (between -0.7 and $-1.7^{\circ} \mathrm{C}$ ), and that the temporal variability of MOW characteristics increases westwards. Since the MWs entering the strait display marked spatial heterogeneity and long-term temporal variability, accurately predicting the characteristics of the MOW into the North Atlantic Ocean appears almost impossible (Millot and García-Lafuente, 2011).

\subsection{The northern WMED}

The northern part of the western basin is the region of WMDW formation, which may occur either over the shelf (dense shelf water cascading) or in the open sea (deep convection). Circulation in the northern WMED is cyclonic with an along-slope current (the Northern Current, see Millot and Taupier-Letage, 2005, for a review) showing intense mesoscale activity. Beyond this area, offshore, there is a central less dynamic zone, known as MEDOC area (MEDOC Group, 1970), where the surface salinity is higher than in the rest of the northern WMED because of a positive $E-P-R$ (evaporation-precipitation-runoff) budget. 


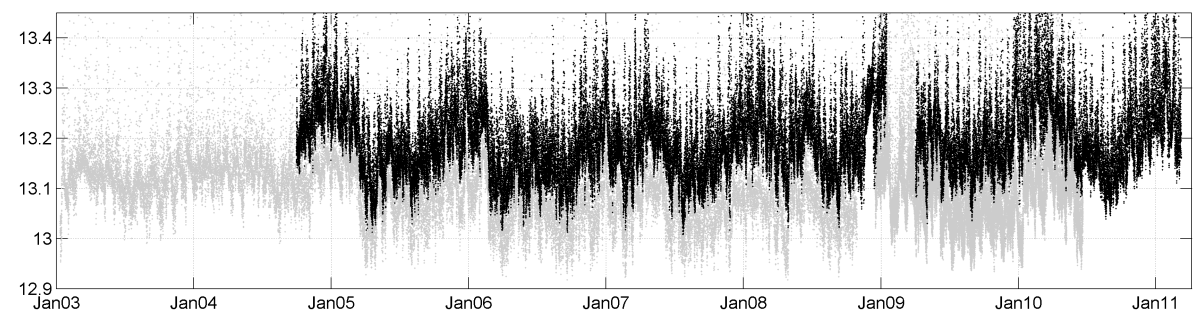

Fig. 4. $\theta$ time series of the MW outflow at CAS (grey dots, at $270 \mathrm{~m}$ ) and at ES (black dots, at $356 \mathrm{~m}$ ).

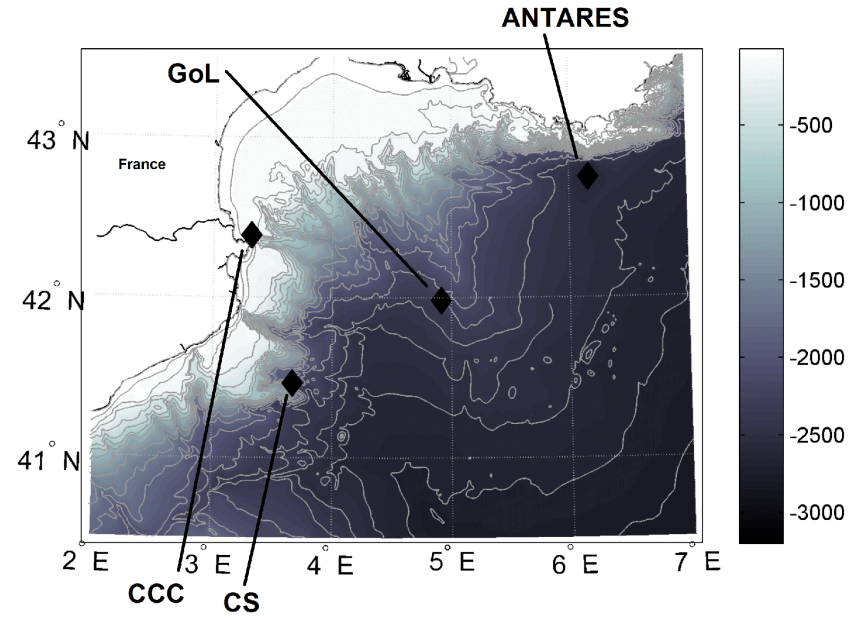

Fig. 5. Location of the four monitoring sites in the north-western Mediterranean $(\mathrm{CCC}=\mathrm{Cap}$ de Creus 39 Canyon; $\mathrm{CS}=$ Catalan slope; GoL $=$ Gulf of Lion, at the centre of the offshore DWF area; ANTARES $=$ ANTARES mooring).

The cyclonic circulation favours low stability in winter enabling the doming of LIW. Once the surface mixed layer is dense and thick enough, bursts of cold, dry northerly winds may trigger deep convection producing the new deep water (open sea convection). Conversely, over the wide shelf of the Gulf of Lion and adjacent areas, $E-P-R$ values are usually lower or even negative because of large river runoff. Despite its low salinity, the cooling of a relatively thin layer of coastal water is sufficiently large to induce a density increase, which eventually is high enough to force the water to sink over the shelf, overfill the shelf-edge and flow down the continental slope, in a process known as cascading, until they reach their density equilibrium at a depth depending on both the severity of the cooling event and the initial $\theta-S$ properties of the coastal waters. Cascading events are characterized by abrupt decreases in water $\theta$ associated with increases in current speed. DWF in the northern WMED is thus the result of highly variable phenomena, which in turn depend on a number of interacting processes, as e.g. air-sea heat exchanges, extreme winds, river discharges, general cyclonic circulation. Such complexity as well as the violent water motions involved, short episodes with high velocities, make this phenomenon difficult to study. Oceanographic cruises cannot be programmed rapidly enough to sample the area at the right moment, and sea conditions can be difficult even for larger ships, so that at best they may provide a certain degree of spatial coverage but lack in temporal resolution. Historical campaigns in the area have focused on convection and not on cascading, which might have been observed only by chance. Thus the HC recorded time series may also provide the opportunity to fully investigate the occurrence of episodes of DWF, both by cascading and open convection. The need of high temporal sampling to resolve events and rapid processes is addressed by the use of moorings located in specific areas where DWF is known to occur. Although the primary goal of $\mathrm{HC}$ is to monitor long-term variability, recent results demonstrated the relevance of the strategy also for accurately detecting, characterizing and monitoring DWF processes and their effects. This has been particularly evident in the relatively short history of the four monitoring sites in the northern WMED (Table 2 and Fig. 5). Winter 2004/2005 was certainly anomalous and very favourable for DWF in the region, both by cascading and open sea convection (Canals et al., 2006; Font et al., 2007; Puig et al., 2008; Palanques et al., 2009; CIESM, 2009).

Figure 6 summarizes the $\theta$ records at the four sites: the Cap de Creus Canyon (CCC), the Catalan slope (CS), the Gulf of Lion (GoL) in the centre of the open sea DWF area and the ANTARES site. It is noteworthy that different scales had to be used to highlight the variability observed at each mooring: $10-14{ }^{\circ} \mathrm{C}$ was necessary for CCC, $12.5-13^{\circ} \mathrm{C}$ for CS, 12.84 $12.92^{\circ} \mathrm{C}$ for $\mathrm{GoL}$, and $12.88-12.93^{\circ} \mathrm{C}$ for ANTARES.

The mooring installed at the head of the CCC (at $315 \mathrm{~m}$ depth), at a level generally occupied by WIW/LIW, recorded the occurrence of cascading from the Gulf of Lion shelf (Fig. 6a). In winter 2003/2004, several cascading events not reaching layers below LIW took place (from January to May) and lasted for a few days, which were generally associated to storms (Palanques et al., 2006). A major continuous cascading event was observed from January 2005 to late March 2005, with strong decreases in $\theta$ (of the order of $3{ }^{\circ} \mathrm{C}$, Fig. 6a) and an increase in current speeds (up to $80 \mathrm{~cm} \mathrm{~s}^{-1}$, see Canals et al., 2006, and Puig et al., 2008). Strong $\theta$ decreases and high current speeds were registered also in winter 2005/2006 (from mid-December to mid-April), while 


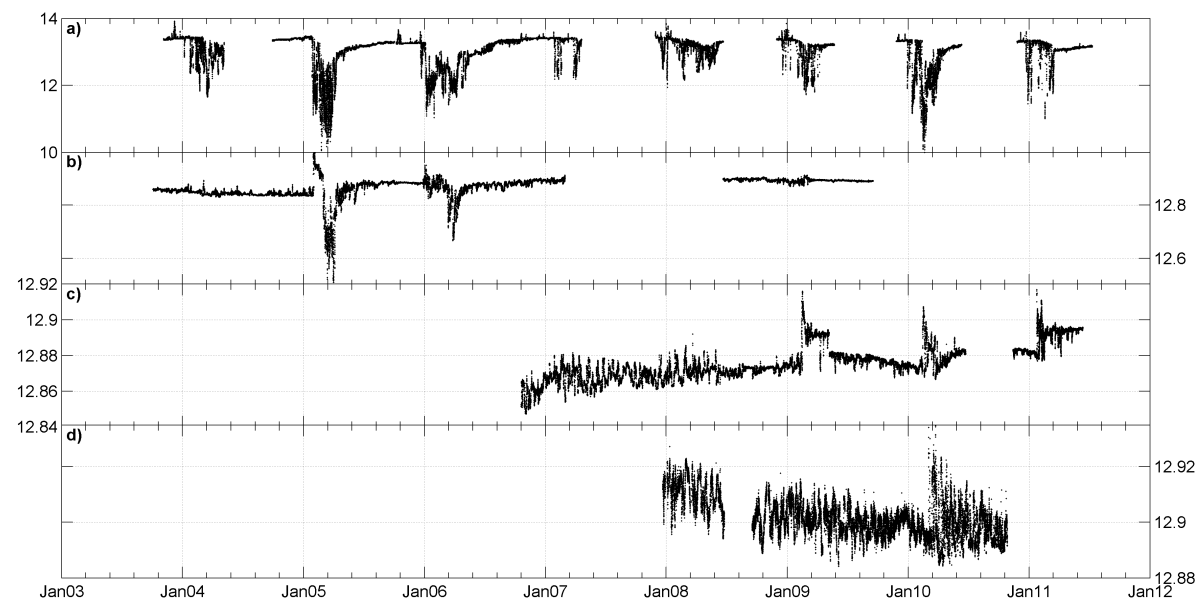

Fig. 6. $\theta$ times series in (a) CCC (at $315 \mathrm{~m}$ ), (b) $\mathrm{CS}$ (at $1875 \mathrm{~m}$ ), (c) GoL (at $2400 \mathrm{~m}$ ) and (d) ANTARES (at $2200 \mathrm{~m}$ ). Note that scales are different.

winters 2006/2007, 2007/2008 and 2008/2009 were characterized only by some minor cascading events lasting for a few days (CIESM, 2009). Cascading at the canyon head in winter 2009/2010 increased its intensity, while winter 2010/2011 was less intense in terms of duration and $\theta$ decrease.

About $120 \mathrm{~km}$ downstream the CCC site, another mooring was installed at $1890 \mathrm{~m}$ on the Catalan slope (CS), located within the WMDW, close to the seabed. This site was chosen because it was previously used in 1993-94 for the study by Send et al. (1996) about the spreading of the new deep waters. So for this location background information was available. $\theta$ (Fig. 6b) and $S$ (not shown) were almost constant from October 2003 (when the mooring has been deployed) until the end of January 2005, indicating a homogeneous water mass with typical WMDW characteristics $\left(12.846 \pm 0.008^{\circ} \mathrm{C}\right.$ and $38.456 \pm 0.002$, respectively), without any seasonal signal (Font et al., 2007; CIESM, 2009). Then both variables suddenly increased to $12.99^{\circ} \mathrm{C}$ and 38.50, respectively, and in early March 2005 they dropped down by more than $0.3^{\circ} \mathrm{C}$ and 0.06 . Such low values were maintained for almost one month and then they gradually increased reaching steady values, which were higher than the initial ones $\left(12.882 \pm 0.005^{\circ} \mathrm{C}\right.$ and $38.481 \pm 0.002$, respectively). Font et al. (2007) attributed the first phase of increasing $\theta$ and $S$ in the CS data to the arrival of dense waters formed by open sea convection, with a large contribution of unusually warm LIW. The sudden cooling and freshening in early March 2005 was interpreted as the arrival of colder and fresher dense shelf waters originated during winter 2004/2005, which cascaded to the lower Catalan continental slope reaching speeds up to $60 \mathrm{~cm} \mathrm{~s}^{-1}$ (Font et al., 2007). The final characteristics $\left(0.04{ }^{\circ} \mathrm{C}\right.$ warmer, 0.03 saltier and $0.012 \mathrm{~kg} \mathrm{~m}^{-3}$ denser) are thus the result of the mixing of the two dense waters formed by open sea convection and cascading, respectively. One year later, another signifi- cant episode was recorded, with a subsequent cooling of the WMDW caused by the winter 2005/2006 cascading pulse, but without significant modification of the background $\theta-S$ properties that were reached at the end of the previous 2005 event. The CS mooring was serviced in early March 2007 without showing any evidence of thermohaline changes in the WMDW associated to the several minor cascading events that occurred in winter 2006/2007 (CIESM, 2009). The gaps between March 2007 and June 2008 and from late 2009 to 2011 are due to a failure in recovering the instruments.

The HC mooring maintained in the bottom layer (where the new WMDW begins its spreading) of the MEDOC area, at the centre of the open sea DWF area $\left(\mathrm{Gol} ; 42^{\circ} \mathrm{N}, 5^{\circ} \mathrm{E}\right.$ at $2400 \mathrm{~m}$ ) by CNRS/COM since October 2006, was serviced in June 2011. The most striking features on this record are the abrupt positive jumps in $\theta$ (Fig. 6c) and $S$ (not shown) that occurred in February 2009, 2010 and 2011, while previous values have been stable at $12.869 \pm 0.005^{\circ} \mathrm{C}$ and $38.479 \pm 0.002$ for more than $2 \mathrm{yr}$. It is interesting to note that $\theta$ first reaches a maximum $\left(12.91-12.92^{\circ} \mathrm{C}\right)$ and then slowly decreases during the following 2 weeks, before finally reaching $12.88^{\circ} \mathrm{C}$. The $\theta$ after each event was a bit higher than before the event, finally reaching (June 2011) values higher than $12.89^{\circ} \mathrm{C}$.

The ANTARES mooring is located offshore Toulon at $2200 \mathrm{~m}$, in the same layer as the GoL mooring. The time series is still quite short, since the SBE37 was added in December 2007 and could not cover the main DWF events of the winters 2004/2005 and 2005/2006. The data show a strong oscillating behaviour, both in $\theta$ (Fig. 6d) and $S$ (not shown), with mean values of $12.90 \pm 0.007^{\circ} \mathrm{C}$ and $38.480 \pm 0.001$, respectively, in line with the records of the other three moorings after the abrupt WMDW warming and salinification in winter 2004/2005. No offshore convection event down to these depths was observed in this easternmost 


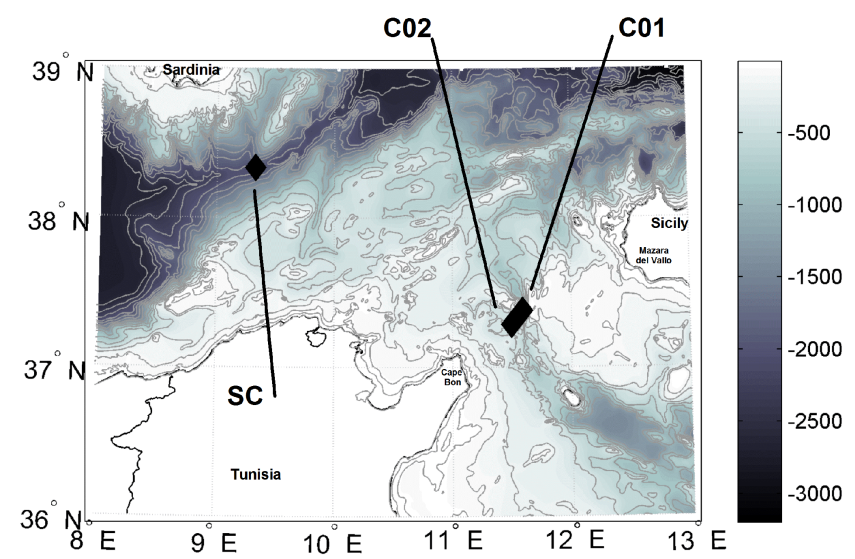

Fig. 7. Location of the three monitoring sites in the central Mediterranean $(\mathrm{SC}=$ Sardinia Channel; $\mathrm{C} 01=$ mooring \#1 in the Sicily Channel; $\mathrm{C} 02$ = mooring \#2 in the Sicily Channel).

location (which is "upstream" of the typical DWF site) in winter $2008 / 2009$, as was in the $42^{\circ} \mathrm{N}, 5^{\circ} \mathrm{E}$ mooring, but the event in winter 2009/2010 was evident also here, with a sud$\operatorname{den} \theta$ increase.

\subsection{The central Mediterranean region}

The central Mediterranean region, i.e. the region between Algeria-Tunisia, Sicily and Sardinia, is the transition zone between the WMED and the EMED. Both surface waters, coming from Gibraltar and intermediate waters from the EMED, cross the region before continuing their paths in the eastern/western part of the Mediterranean, respectively. Figure 7 shows the precise location of the three monitoring sites in this region.

The Sardinia Channel (SC) is a wide opening between Tunisia and Sardinia, which has a sill at about $1900 \mathrm{~m}$ in a narrow deep trench that allows exchanges of the upper part of the deep waters to occur between the Algerian and the Tyrrhenian subbasins (Astraldi et al., 1999). The densest part of WMDW, which is trapped in the Algerian subbasin, is thus overflowing the sill when uplifted by even denser WMDW. The less dense WMDW, circulating anticlockwise and alongslope may enter the Sardinia Channel directly following the Algerian slope. These two parts of WMDW will thus be located at different places in the channel, and the HC mooring being at the sill (Fig. 7) is thought to chiefly monitor the overflowing dense WMDW. The other water mass exchanged in this region results from the mixing, inside the Tyrrhenian, between the WMDW and waters of eastern origin. In particular, the sinking of the Eastern Mediterranean Overflow Water (EOW) from depths shallower than $400 \mathrm{~m}$ down to $2000 \mathrm{~m}$ induces a tremendous mixing of the EOW itself and of the EOW with the resident water in the Tyrrhenian (Millot, 1999), giving origin to the TDW. The monitoring in the $\mathrm{SC}$ is operated at the sill (Fig. 7) in order to observe the variability of the deep water exchanged between the two adjacent subbasins. The $\theta$ time series (Fig. 8a) collected at the sill since July 2003 (salinity not shown) shows an alternation of WMDW presence (lower $\theta$ and $S$, between 12.81 and 12.86 , and $\sim 38.45$; generally flowing eastward) and TDW presence ("pulses" of higher $\theta$ and $S,>12.86$ often exceeding $12.9^{\circ} \mathrm{C}$, and $S>38.46$ sometimes $>38.48$; generally flowing westward) (see also Bouzinac et al., 1999). Those TDW pulses are generally of short duration (between 1 day and 1 week), and are likely to be due to displacements of the interface between the two deep water masses. Thus the mooring alternatively sampled WMDW (mainly) and TDW. Further we may observe a constant increase of $\theta$ in the WMDW (about $+0.05^{\circ} \mathrm{C}$ in $5 \mathrm{yr}$ ). On the contrary $S$ (not shown) exhibits a decrease in the first half of the time series, between July 2003 and September 2005, followed by a stronger $S$ increase. A closer look at the $\theta$ time series also shows that the increasing tendency is accelerated after September 2005 (about $+0.38^{\circ} \mathrm{C}$ in $2.5 \mathrm{yr}$; for comparison, we note that Fuda et al., 2002, reported a similar increasing trend of $0.016^{\circ} \mathrm{C} \mathrm{yr}^{-1}$ in the deep Tyrrhenian during the 1990s).

The Sicily Channel separates the sea into its two basins, the EMED and the WMED, and it is the most important Mediterranean passage after Gibraltar. As at Gibraltar, there is a two-layer system that is maintained by the excess of evaporation over the EMED. Its monitoring is fundamental for the quantification of the highly variable exchanges between the two basins, in particular of the heat and salt import from the EMED to the WMED (and thus towards the DWF region and the Strait of Gibraltar). The channel is a complex region, delimited by two sill systems and a deep basin between them. Both the eastern and the western sill systems are in the $400-500 \mathrm{~m}$ depth range, while the internal portion reaches a depth of $1700 \mathrm{~m}$, and plays a role as a buffer zone. Between Cape Bon (Tunisia) and Mazara del Vallo (Italy), a ridge divides the channel longitudinally into two trenches each with very different cross-sectional areas (Fig. 7). The axis of the Sicilian trench and adjacent to the wide Sicilian plateau is directed northwards, is very narrow, and has a maximum depth of $450 \mathrm{~m}$ (mooring C01). The Tunisian trench is wider, shallower, and with a sill depth at about $530 \mathrm{~m}$ located some $20 \mathrm{~nm}$ to the south-west of the other (mooring C02). The monitoring of the bottom layer in both trenches (where the intermediate waters and the upper part of the deep waters of eastern origin pass) started in 1993, well before the start of HC. This data set presently constitutes one of the longest, uninterrupted Mediterranean time series (along with the Corsica Channel series, the DYFAMED and the CEFREM - Centre de Formation et de Recherche sur l'Environnement Marin- series). These data were of particular relevance in documenting the propagation of the EMT signature from the eastern to the western basin. The exceptionally large volume of new deep waters of Aegean origin (Roether et al., 2007) produced during the EMT modified the 


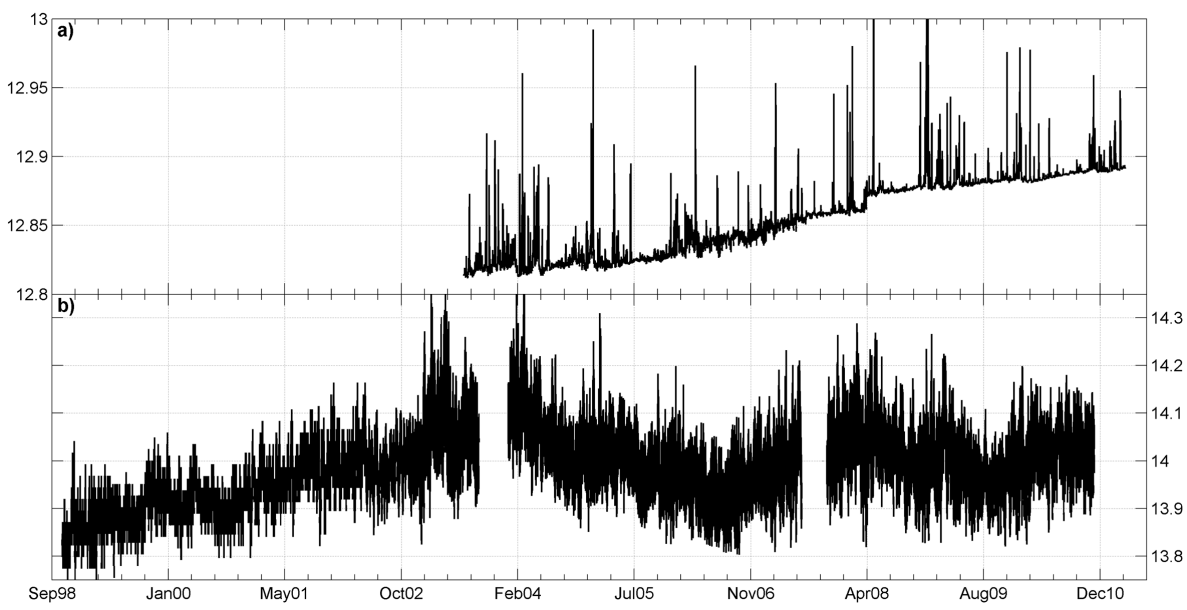

Fig. 8. (a) $\theta$ time series at $\mathrm{SC}$ (at $1900 \mathrm{~m}$ ), (b) $\theta$ times series in at $\mathrm{C} 01$ (at $387 \mathrm{~m}$ ).

thermohaline characteristics of the intermediate layer in the channel (traditionally occupied by LIW) and induced the uplifting of the resident deep waters in the Ionian, significantly increasing the volume of EOW crossing the Sicily Channel towards the Tyrrhenian subbasin (Gasparini et al., 2005).

Presently the sub-surface moorings, which measure currents, $\theta$ and $S$ at different depths, monitor the exchanges both in the surface and the deep layers. In the bottom layer, moorings are equipped with a high quality CTD probe to detect the hydrological variability in correspondence to the intermediate water layer (Table 2). The $\theta$ time series (shown since October 1998, Fig. 8b) at C01 at $400 \mathrm{~m}$ depth gives evidences of the high variability of the water masses crossing the channel. This variability is related to the intense mesoscale dynamics in this region (Sammari et al., 1999) and the presence of new water masses in the transition layer (Ben Ismail et al., 2012). Data collected at C02 (not shown) have comparable patterns but are on average $0.04{ }^{\circ} \mathrm{C}$ colder than in $\mathrm{C} 01$. This is explained by the dynamics of the channel, which forces the core of LIW (warmer and saltier than the surroundings) to flow mainly through the eastern passage (Ben Ismail et al., 2012).

An investigation of the interannual variability reveals that $\theta$ presents a cycle with warming and cooling periods. More in detail, a warming period is well evident between October 1998 and July 2004, with a mean increase of $0.15^{\circ} \mathrm{C}$ (from $13.89^{\circ} \mathrm{C}$ to $14.04^{\circ} \mathrm{C}$, Fig. 8b). After July 2004 a strong cooling occurred $\left(-0.10^{\circ} \mathrm{C}\right)$, which lasted to June 2006 , followed again by a warming period (peaked in March 2008, when $14.02^{\circ} \mathrm{C}$ was reached in the low-passed time series). The final part of the time series shows again the beginning of a cooling period. Higher frequencies are superimposed to this trend: there is a seasonal cycle of $0.05^{\circ} \mathrm{C}$ amplitude peak-topeak (maximum $\theta$ in late winter-early spring, probably due to the stronger presence of LIW in this period, which forms in winter in the EMED, and minimum $\theta$ in late autumn), and

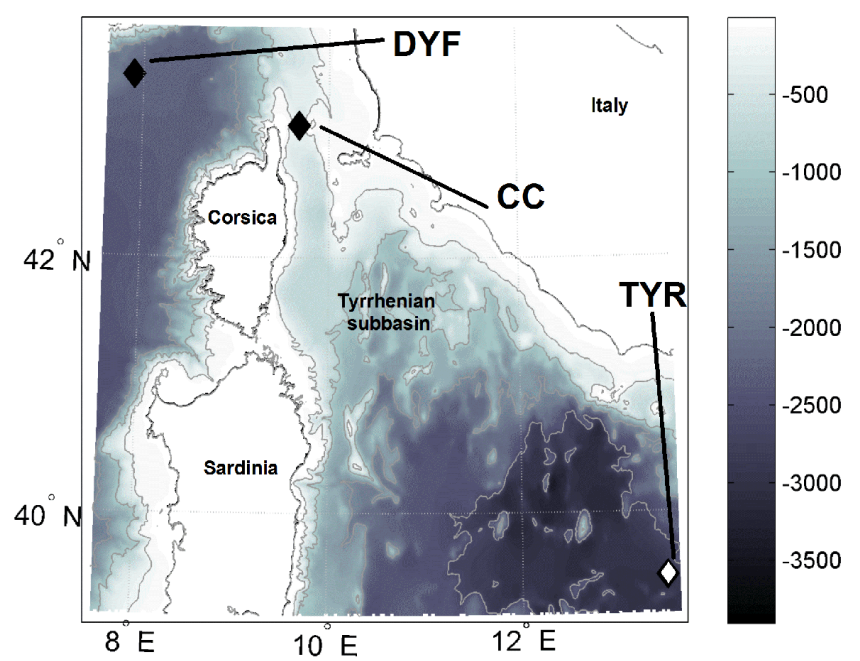

Fig. 9. Location of the monitoring sites in the TyrrhenianLigurian subbasins $\quad(T Y R=$ Tyrrhenian, $C C=$ Corsica Channel, $\mathrm{DYF}=\mathrm{DYFAMED})$.

numerous higher frequency variations of the order of days or weeks, suggesting a pulsating nature of the flow crossing the channel. Indeed Astraldi et al. (1999) and Grancini and Michelato (1987) found that the flow undergoes pulses with a period of about 15-20 days. It is worth to note that part of this variability may also be ascribed to the intense mesoscale activity of that region (Sammari et al., 1999), which would be able to modify the slope of, or raise and lower, the interface between water masses.

\subsection{The Tyrrhenian and Ligurian subbasins}

The Ligurian and Tyrrhenian are two of the WMED subbasins that are connected through the Corsica Channel (Fig. 9), with a sill depth of about $460 \mathrm{~m}$ and a surface width of $30 \mathrm{~km}$. The Ligurian subbasin has a cyclonic circulation, 
with a marked seasonal variability: the Northern Current is more intense and also more unstable in winter than in summer (Taupier-Letage and Millot, 1986). The Tyrrhenian circulation presents a well developed mesoscale activity and a mean cyclonic circulation that is less intense than the Ligurian circulation (Krivosheya and Ovchinnikov, 1973; Vetrano et al., 2010). In this region $\mathrm{HC}$ is operating three stations (see Fig. 9): in the deep southern Tyrrhenian, within the shallow Corsica Channel and in the central part of the Ligurian subbasin, close to the historical DYFAMED station, $30 \mathrm{~nm}$ off the French Riviera.

The Tyrrhenian is a deep subbasin characterized by a complex bottom bathymetry. It has a narrow and shallow northern opening toward the Ligurian subbasin (the Corsica Channel) and a much larger and deeper opening in the south, a $250 \mathrm{~km}$ wide passage between Sardinia and Sicily. Beyond this opening, there is a deep communication toward the western Algerian subbasin (through the Sardinia Channel) and an eastern shallow connection to the EMED (through the Sicily Channel). As mentioned in the previous section, through the Sicily Channel the Tyrrhenian receives the LIW, which is marked by a subsurface temperature and salinity maximum, and the EOW, which mixes with the surface AW above and the deeper water masses below. One product of this mixing, below $700 \mathrm{~m}$ down to the bottom, is the TDW. The deep mooring in the southern Tyrrhenian (Fig. 9) is placed in a relevant site to be monitored for a number of peculiar characteristics: it has relatively weak dynamics (Vetrano et al., 2010), making it a suitable site to monitor the long term evolution of hydrographic properties of deep water masses (Gasparini et al., 2005); it has a highly oligotrophic regime and appears to have been a net $\mathrm{CO}_{2}$ source for the atmosphere from the 1960s to the 1980s and only transformed into a sink in the 1990s (Louanchi et al., 2009); it is a salt fingering region characterized by the presence of thermohaline staircases in the deep layers (Zodiatis and Gasparini, 1996), subject to internal waves which modify the vertical fluxes. Two $\theta$ time series are shown in Fig. 10a, at $3880 \mathrm{~m}$ and at $2524 \mathrm{~m}$ depth. They have a similar variability of about $0.03^{\circ} \mathrm{C}$ with the deeper one being about $0.05^{\circ} \mathrm{C}$ cooler than the shallower one. The frequent sudden $\theta$ jumps are a striking feature that might be indicative of internal waves passing by and displacing the interfaces of the thermohaline staircases, which are typical for the deep central Tyrrhenian subbasin (stairs of 20-54 m thickness, separated by thinner interfaces of about 2-27 m, as reported by Zodiatis and Gasparini, 1996). The time series is still too short for any further analysis of longterm processes.

Historical observations show that the Corsica Channel (CC) is crossed by a two-layer shear flow with an upper layer of AW and a lower layer of LIW (Astraldi et al., 1987). Longterm velocity measurements (Astraldi et al., 1999) show that there is a northward flow with clear seasonal variability. The highest velocity occurs in winter, when the flow crossing the channel is about $60 \%$ of the annual transport. The exchanges through the $\mathrm{CC}$ are being monitored without interruptions since July 1985, well before the start of the HC network. The $\theta$ time series at $400 \mathrm{~m}$ depth (Fig. 10c) is able to capture the hydrological variability of the LIW layer. The highest $\theta$ of the whole record was recorded in early 2005 (more than $13.9^{\circ} \mathrm{C}$ ) and then again in February 2010: compared to the mid 1980 s, when the average was $13.55^{\circ} \mathrm{C}$, up to 2005 there has been an increase of $+0.35^{\circ} \mathrm{C}$. After winter $2004 / 2005$ the $\theta$ at $400 \mathrm{~m}$ dropped suddenly to the lowest value of the whole record, reaching $<13.35^{\circ} \mathrm{C}$ in spring 2006 , and recovered shortly after again to $13.6^{\circ} \mathrm{C}$. It is interesting to note that within one year (early 2005-early 2006) the highest and the lowest values of the 1985-2010 time series were observed. Part of the variability in the channel may be explained by the seasonal cycle, with the drops in $\theta$ (and $S$, not shown) being caused by the intrusion of intermediate water coming from the north. Air-sea fluxes differences and steric differences between the two basins, also related to DWF events in the Ligurian subbasin and in the north-western Mediterranean, are possible candidates to explain the variability of the $25-\mathrm{yr}$ $\theta$ time series. According to Astraldi and Gasparini (1990) a link can be established between the winter increase of the current in the CC and the cooling of the Ligurian subbasin induced by episodes of significant heat loss. In particular, the oscillating behaviour of the final part of the series might be connected to the fact that the north-western Mediterranean seems to have become a quite active DWF site recently, i.e. since 2005 (CIESM, 2009).

The Ligurian subbasin comprises the area east of the Gulf of Lion and north of the island of Corsica, characterized by a basin-scale cyclonic circulation (Crépon et al., 1982) with strong currents around its edge, the Northern Current flowing close to the Italian and French coasts and the western Corsica Current (Astraldi and Gasparini, 1992) flowing west of Corsica. This cyclonic gyre has been attributed to geostrophic adjustment to winter deep-water formation (Crépon et al., 1989) and the influence of cyclonic wind stress curl (Herbaut et al., 1997). The DYFAMED site is located in the central Ligurian subbasin, where the water depth is $2350 \mathrm{~m}$. Thanks to monthly CTD monitoring programme at this site, a steady increase of $\theta$ and $S$ has been detected in the deep waters during 1995-2005 (Marty and Chiaverini, 2010). In February 2006, an abrupt increase in $\theta\left(+0.1^{\circ} \mathrm{C}\right)$ and $S(+0.03)$ was measured at $2000 \mathrm{~m}$ depth as the result of successive intense DWF events during the three preceding years and as a signal of the EMT event (Schroeder et al., 2008). Since August 2009, and in the framework of HC, the WMDW (at $2000 \mathrm{~m}$ ) and the lower LIW (at $700 \mathrm{~m}$ ) are continuously monitored (Fig. 10b). Currently, the $\theta$ at $2000 \mathrm{~m}$ depth is decreasing slowly down to $12.90^{\circ} \mathrm{C}$. At $700 \mathrm{~m}$ depth the $\theta$ shows a strong seasonal and interannual variability (between $12.95^{\circ} \mathrm{C}$ and $13.35^{\circ} \mathrm{C}$ ). The $\theta$ minimum has been observed during the full water column mixing (winter 2005-2006, as reported in Schroeder et al., 2010) and presently $\theta$ is reaching $13.2^{\circ} \mathrm{C}$ (Fig. 10b). 

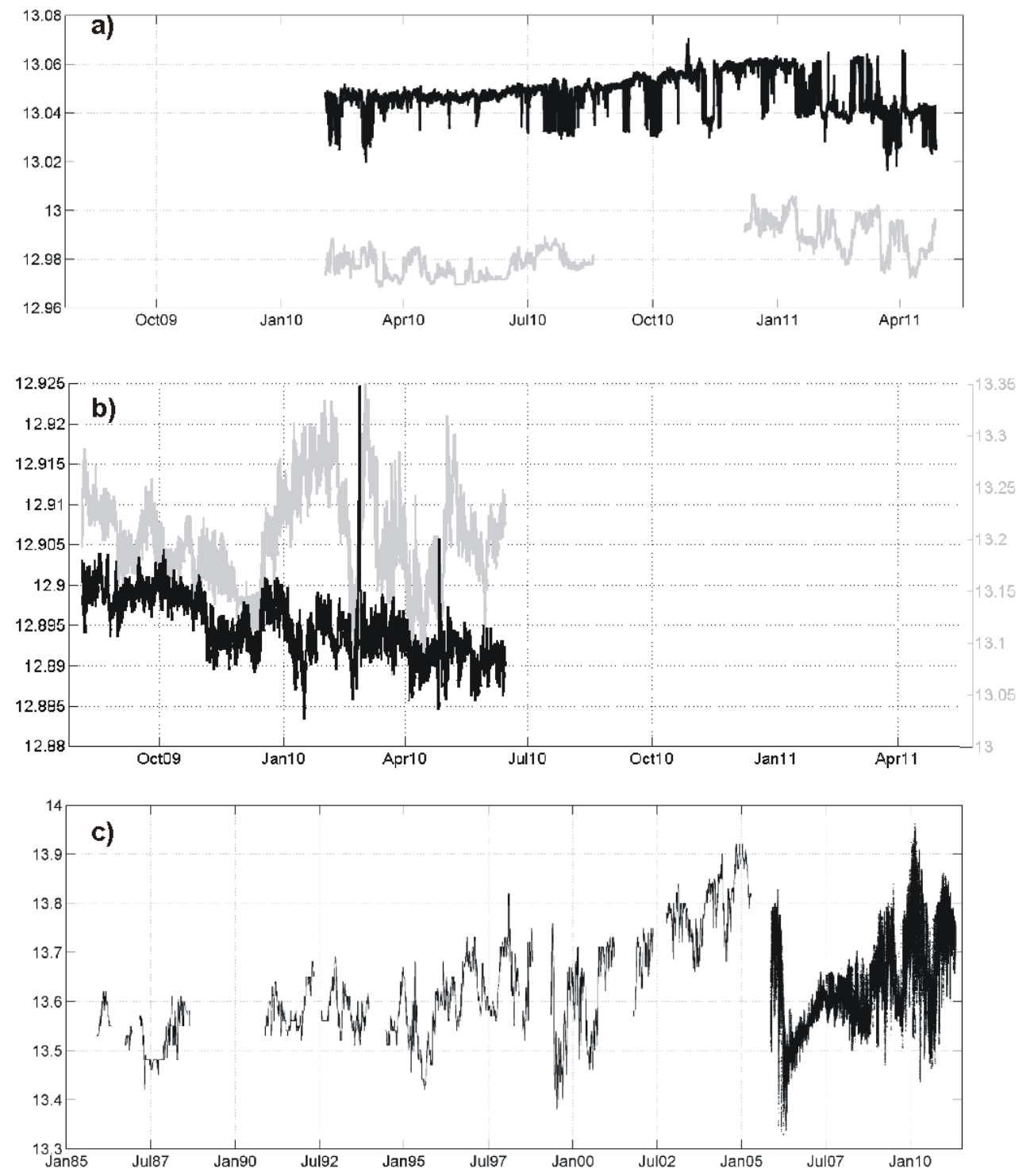

Fig. 10. $\theta$ time series in (a) TYR (black at $2524 \mathrm{~m}$, grey at $3380 \mathrm{~m}$ ), (b) DYF (black at $2000 \mathrm{~m}$, grey at $700 \mathrm{~m}$ ) and (c) CC (at $400 \mathrm{~m}$ ), where the first part of the record has been done with an Aanderaa current meter (precision of $0.05^{\circ} \mathrm{C}$ ), while since late 2005 it has been replaced by a more precise $\operatorname{SBE} 37\left(0.001^{\circ} \mathrm{C}\right)$.

\subsection{The Southern Adriatic}

Like the northern WMED, also the Adriatic is an area of DWF (Artegiani et al., 1997) with a negative heat budget as a result of the strong heat loss due to the outbreaks of cold continental air from the Balkan Peninsula (Bora Wind) over the area. The formation of dense water masses within this subbasin implies an outflow of cold and dense water at the bottom through the Otranto Channel. In particular, the Adriatic is a source of the EMDW, which is formed under favourable oceanographic and climatic conditions (Ovchinnikov et al., 1985). Two types of DWF occur during winter within the Adriatic: open ocean convection forming the major portion of the AdDW inside the southern Adriatic Pit, and the dense shelf water cascading process taking place on the continental shelf of the north and middle Adriatic, forming the Northern Adriatic Dense Water (NAdDW). The latter flows southward and sinks to the bottom of the southern Adriatic Pit (Ovchinnikov et al., 1985; Bignami et al., 1990; Malanotte-Rizzoli, 1991), filling its deepest part and displacing the resident warmer and less dense AdDW at shallower levels $(800-1000 \mathrm{~m})$. This water flows into the Ionian subbasin along the bottom of the Otranto Channel, more or less adjacent to the western shelf slope.

Since the late 1980s, the southern Adriatic Pit has been monitored almost every year because of its importance in driving the EMED deep circulation convection cell. The 


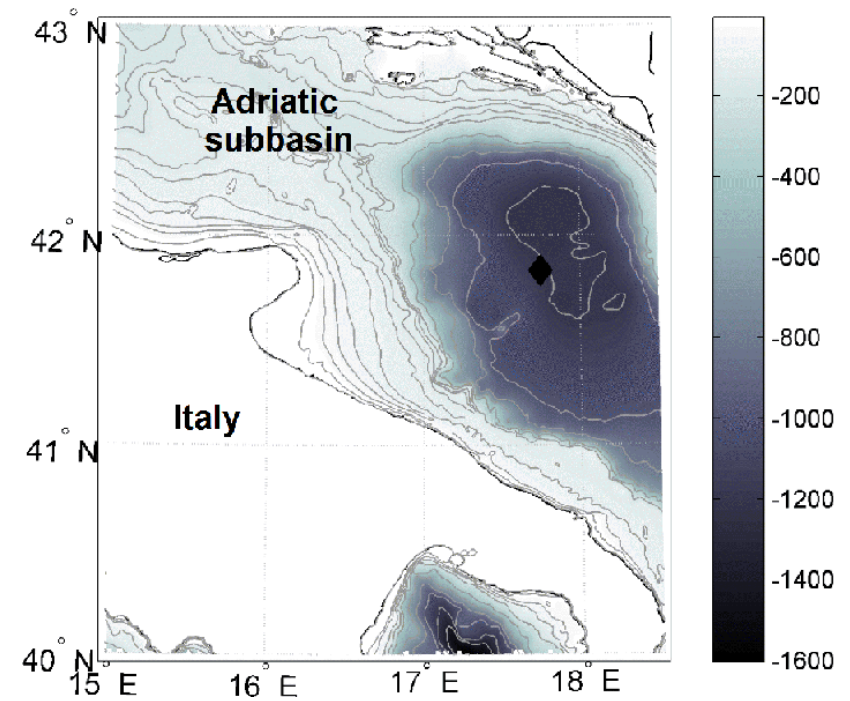

Fig. 11. Location of the monitoring site in the southern Adriatic.

monitoring site E2M3A (part of EuroSITES and OceanSITES networks) is located in the pit (Fig. 11), in the centre of a quasi-permanent cyclonic gyre (Gačić et al., 2001, 2002). It is an area where vertical mass transfer (upwelling, winter convection) has a rather prominent role in distributing physical and chemical water properties and controlling the primary production. The recorded time series can be used for studies of long-term changes of the Adriatic response to local climatic forcing and the volume of the dense water formed as a function of the winter heat losses (Cardin and Gačić, 2003). The amount of the dense water formed also determines the water exchange between the Adriatic and the rest of the EMED (Manca et al., 2002; Cardin and Gačić, 2008). The first attempt to deploy a mooring in the area dates back to 2003, when only 9 months of data were recorded. The present mooring has been deployed in November 2006 (Table 2) and is equipped also with instruments monitoring the thermohaline characteristics of the intermediate and deep layer. Figure 12 shows the $\theta$ time series at 5 different depths. At $1172 \mathrm{~m}$ (sampling the resident and the newly formed deep water) a constant increase of $\theta$ may be observed between November 2006 and September 2010 (linear trend of $\sim 0.05^{\circ} \mathrm{C} \mathrm{yr}^{-1}$, i.e. from $12.82^{\circ} \mathrm{C}$ to $13.01^{\circ} \mathrm{C}$ ). Also, salinity underwent a similar positive trend in the bottom layer (linear trend of $\sim 0.004 \mathrm{yr}^{-1}$, not shown). Even if it is a quite short time series, which is not representative of longer-term changes, it is interesting to note that the increasing trend seems to be much higher than in any other location. It is likely that this bottom trends are a consequence of the interaction with dense waters coming from the northern Adriatic. Indeed, a general increase in the salt content observed in the southern Adriatic until 2007 (Cardin et al., 2011) and the lack of freshwater contribution (of the Po River) may have strengthened the salinity increase in the dense waters pro-

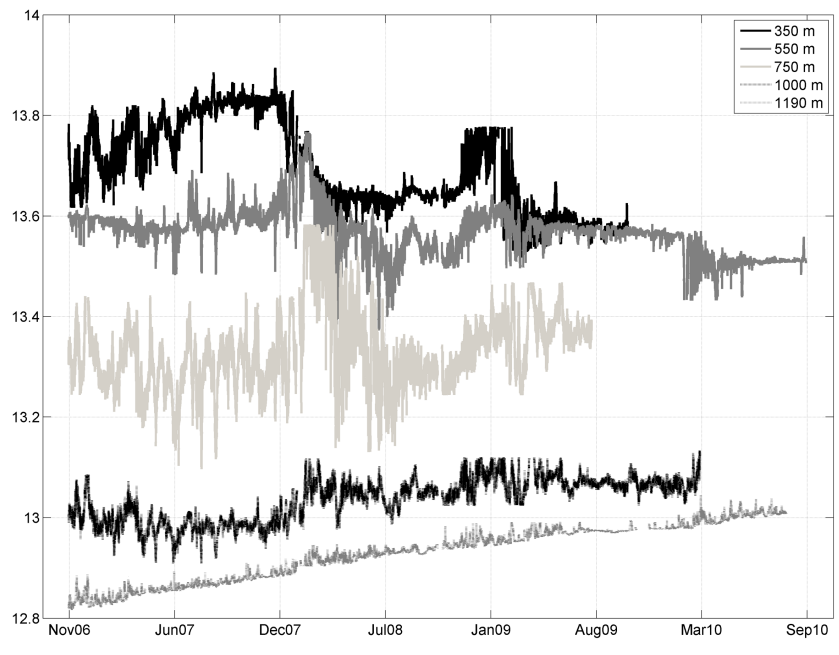

Fig. 12. $\theta$ time series in the southern Adriatic at different depths (see legend).

duced on the northern shelf during winters. Time series at different depths (Fig. 12) show the absence of convective mixing processes during winter 2006/2007, while they are well evident during winter 2007/2008, when they reached a maximum depth of about 700-800 m in February 2008 (Cardin et al., 2011).

\subsection{The Cretan Straits}

The Cretan Arc region separates the southern Aegean subbasin from the rest of the EMED and the water exchanges between them occur through a series of straits along the Cretan Arc, the so-called Cretan Straits. The Antikythira Strait at the western part of the Cretan Arc (Fig. 13), with a sill depth of $\sim 870 \mathrm{~m}$ is one of the two straits through which deep water exchanges can occur (Astraldi et al., 1999; Kontoyiannis et al., 2005). The exchanges through the Cretan Straits are of considerable importance because they are a substantial part of the EMED thermohaline circulation, particularly in relation to the EMT (Theocharis et al., 1992, 1999; Roether et al., 1996). Until the mid-to-late 1980s, waters of Aegean (Cre$\tan$ ) origin were usually observed south of the Cretan Arc, between LIW and EMDW. However, at the end of the 1980s the water exchanges through the Cretan Straits were drastically modified as a result of substantial changes in the basins hydrology, inducing a massive outflow of Cretan Deep Water (CDW) that filled the deep and bottom layers of the EMED. These changes have significantly affected the deep thermohaline cell of the EMED, and it has been shown that their effects have been observed spreading to the Otranto (Astraldi et al., 1999; Klein et al., 1999) and the Sicily channels (Gasparini et al., 2005), at the western boundaries of the EMED. The $\theta$ time series at $850 \mathrm{~m}$ within the channel where the CDW outflows (Fig. 14) shows a notable variability, including episodic events that last a few days and occur mostly during 2007, 


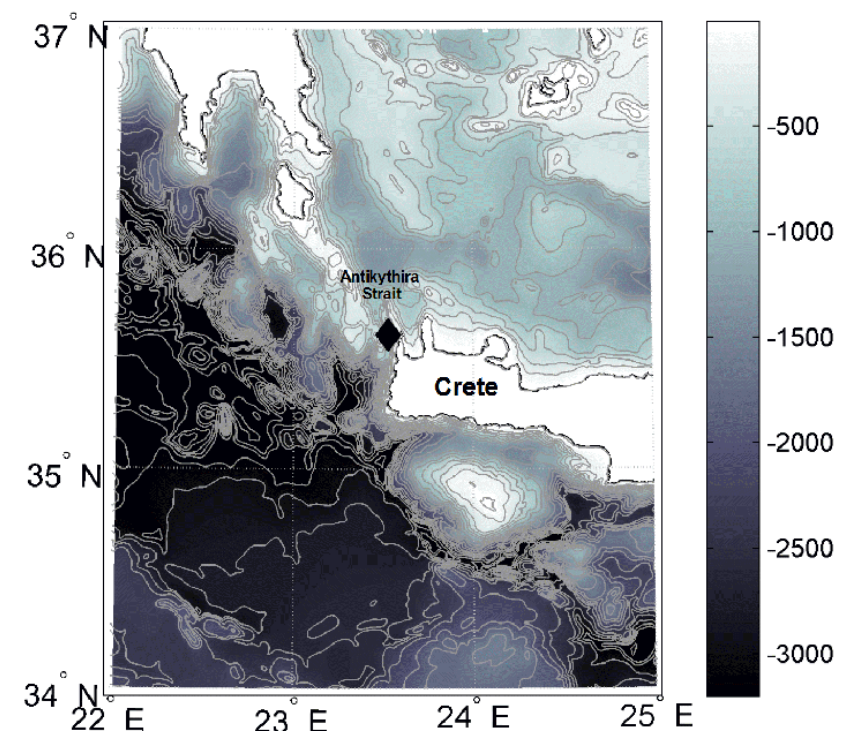

Fig. 13. Location of the monitoring site in the Cretan Strait.

2008 and 2009. The values of $\theta$ range between 13.60 and $14.64^{\circ} \mathrm{C}$. The $S$ variability (not shown) is directly related to the $\theta$ so that $\theta$ highs/lows correlate with $S$ highs/lows. In the summer period, when the warm and salty CDW is reduced, it is very likely that colder and less saline characteristics prevail due to the influence of the colder/fresher overlying Transitional Mediterranean Water (TMW), which occasionally is found in the Cretan Strait area around $\sim 600-700 \mathrm{~m}$, just above the CDW (Kontoyiannis et al., 2005). The potential density is mainly driven by salinity and varies mostly between 29.19 and 29.20. Higher potential densities occured in winter 2008/2009 with episodic peaks that reached 29.21. In summer 2010, the variability of $\theta$ (and $S$, not shown) is substantially reduced (after the 1-yr data gap), denoting a more persistent presence of TMW. In mid-November 2010 a sharp $\theta$ and $S$ increase $\left(0.75^{\circ} \mathrm{C}\right.$ in 5 days) with potential densities near 29.21 denotes the reappearance of CDW in the Strait.

\section{Discussion}

The various time series described in the previous section show some common features that deserve to be discussed. We will mainly focus on the north-western Mediterranean, the Strait of Gibraltar, the Sardinia Channel and the intermediate water characteristics at the Sicily Channel, the Corsica Channel and the DYFAMED station, in order to answer a number of questions and to make an attempt to explain the observed variability.

As pointed out previously, the HC time series demonstrated their relevance to accurately detect effects of the DWF processes and to follow a signal from DWF areas up to the straits and passages between basins, thus giving insights into the functioning of the sea, not only of specific processes. This is particularly evident in the records of the four $\mathrm{HC}$ sites in the north-western Mediterranean (Figs. 5 and 6), showing the succession of dense shelf water cascading and open sea convection in early 2005 and 2006 . The sudden variations described above precede abrupt $\theta$ and $S$ increases observed by other authors in the deep WMED in spring 2005 (LópezJurado et al., 2005; Schroeder et al., 2006, 2008), which were explained as a consequence of anomalous WMDW formed during exceptional winters. The effects of the 2005 and 2006 DWF episodes have been extensively documented in the recent literature, using data collected during several basin-wide cruises (Schroeder et al., 2008). Repeated CTD transects since 2005 evidenced a rapid filling of the western basin with newly formed warmer and saltier deep waters, inducing dramatic changes of the hydrological structure and considerable renewal of previous waters (CIESM, 2009). The time series collected in the north-western Mediterranean have allowed documenting the sequence of changes experienced by the WMDW during the major 2005 and 2006 cascading events. In particular, the mooring in the Catalan slope (CS in Fig. 5) recorded major features related to those DWF events (Fig. 6b): it captured the arrival of open sea convection waters (positive jumps of $\theta$ and $S$ in late January 2005), followed by the arrival of dense shelf waters (drop in $\theta$ and $S$ in early March), and a stabilized (but warmer and saltier) situation after April 2005. A similar succession of events was recorded one year later (CIESM, 2008, 2009; Fig. 6b). Evidences of dense water cascading are present every year at CCC (Fig. 6a), although dense shelf waters reach the basin occasionally. DWF seems to have been occurring in early 2009 and 2010, as shown also by the hydrological and dynamical features recorded at the deep monitoring sites, GoL and ANTARES in Fig. 5 (at GoL also in 2011, Fig. 6c), with an abrupt positive jump in $\theta$ and $S$ in mid-February (signature of only offshore convection, no dense water cascading). The time series indicate a clear difference between winters characterized by minor or major cascading events.

The marked increases of $\theta$ (Fig. 8a) and $S$ (not shown) in the Sardinian Channel (SC in Fig. 7) since September 2005 are likely to contain the remote signal of what happened in the northern WMED (i.e. the formation of an anomalously warm and salty new WMDW), as shown also by repeated CTD casts in this area, with the warm and salty deep water formed during 2005 and 2006 slowly passing through the channel to reach the Tyrrhenian subbasin (CIESM, 2009). As stated in Sect. 3.3, it has been shown that records with such high temporal resolution are able to evidence the pulsating flow at the mooring depth of TDW (warmer and saltier), which is usually located above the colder and fresher WMDW layer. The pulsating nature of these features could be further investigated, using statistical tools such as wavelets, to allow the temporal windowing of specific frequencies of variability. Without the HC strategy of long-term, high resolution records such an analysis would be unfeasible. 


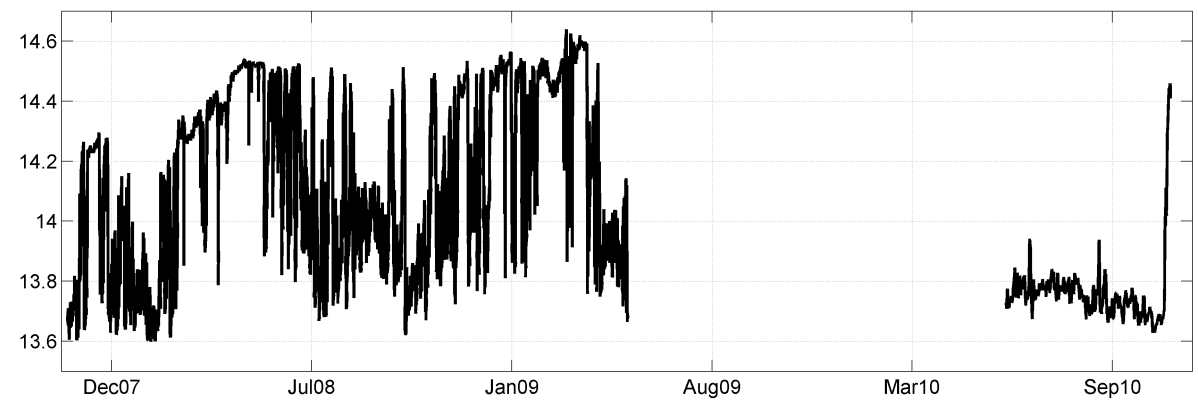

Fig. 14. $\theta$ time series in the Cretan Strait (at $850 \mathrm{~m}$ ).

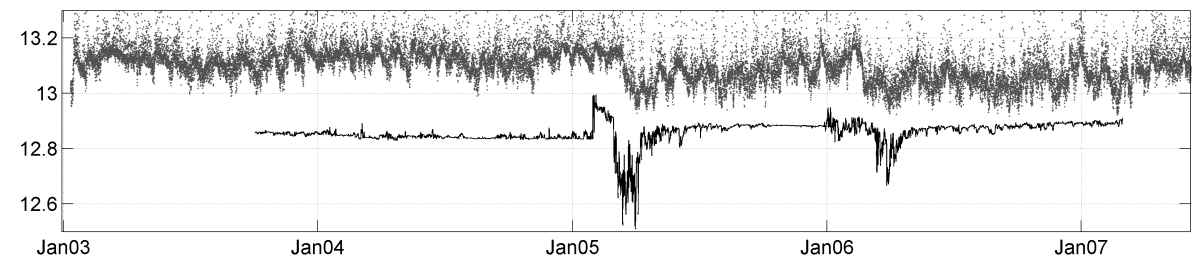

Fig. 15. Comparisons between $\theta$ time series at Camarinal Sill, Gibraltar (in grey), and on the Catalan slope (in black).

García-Lafuente et al. (2007) found a signature of the DWF events in the MOW (Fig. 15). At Gibraltar (CAS and ES in Fig. 2), the significant $\theta$ drop observed in March 2005 and March 2006 in the outflowing water might be directly related to a propagating baroclinic signal triggered by the DWF events recorded some weeks earlier by the $\mathrm{HC}$ mooring in the north-western Mediterranean (CIESM, 2009). The new WMDW formed there could have replenished the WMDW reservoir and raised its interface with the water above, making cooler water available for the outflow (García-Lafuente et al., 2007, 2009). Figure 15 shows the comparison between the two time series (at Gibraltar and the Catalan slope), where the remarkable temporal match between the springtime cooling signals in both series seems to confirm this hypothesis. According to these authors, even if this $\theta$ drop happens almost every year, in 2005 and in 2006 unusually sharp decreases were recorded. However, because these $\theta$ drops occur nearly one month apart during these two years, and because they seemingly occur between two spring-tide periods, they could also be due to tidal mixing processes, hence just evidencing a local wintertime event independent from DWF (Millot, 2013). Finally, it is worth to stress that the role of the AW inflow variability at Gibraltar (MS in Fig. 2, time series in Fig. 3) should be definitely considered in the study of DWF processes in Mediterranean Sea and in the characteristics of the resulting waters, especially with regards to salinity variations (Millot, 2007, 2008). As a matter of fact, decadal trends of $\theta$ in some deep MWs formed may be partially a consequence of $S$ trends in the AW entering the sea, as less wintertime heat loss is required to make a saltier surface water sink to greater depths and be transformed into intermediate and deep MWs (Millot, 2007; Schroeder et al., 2008).
The monitoring of the hydrological properties in the Sicily Channel allowed Gasparini et al. (2005) to observe the evolution of water masses under the influence of the EMT. According to these authors, the signal of the climatic transient reached the WMED in 1992, modifying the properties of the intermediate and deep layers. According to Schroeder et al. (2006) the recent sudden change in the deep layer structure, heat and salt contents in the WMED may be related not only to severe winters but also to a decadal salt and heat accumulation at intermediate levels, induced by the arrival of the EMT signal first in the Tyrrhenian and then in the Ligurian subbasins. More recently, also Gacic et al. (2013) discussed this issue, correlating the thermohaline time series in the Sicily Channel with those in the Levantine and Ionian subbasins. They hypothesized the periodical variability of the general circulation of the Ionian (see Pinardi and Masetti, 2000; Demirov and Pinardi, 2002; Borzelli et al., 2009; Gacic et al., 2010, 2011) produces changes in the propagation of the LIW towards the WMED and thus may be a causal factor for the WMT.

Comparing the time series at $400 \mathrm{~m}$ along the path of the LIW (coming from the EMED, it crosses the Sicily Channel, then the Tyrrhenian, from where it flows partially through the Corsica Channel towards the Ligurian subbasin), a gradual decrease of $\theta$ (Fig. 16) and $S$ (not shown) may be observed from the Sicily Channel to the Corsica Channel and to the Ligurian subbasin, due to its gradual mixing with the surface and deep waters. The DYFAMED data are collected (CTD casts) on a monthly basis in the Ligurian subbasin since 1991 (Fig. 16 shows the $400 \mathrm{~m}$ time series). The most striking feature is that there is an interannual oscillation in all three time series, with increasing $\theta$ until 2004, followed 


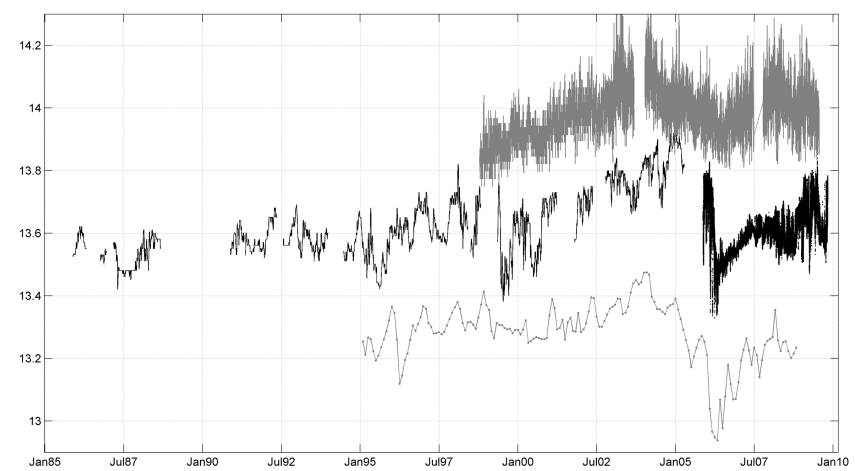

Fig. 16. Comparison between $\theta$ time series at $400 \mathrm{~m}$ depth at the Sicily Channel (top), the Corsica Channel (middle), and at DYFAMED (bottom). All values refer to $400 \mathrm{~m}$ depth.

by a sharp decrease until spring 2006 and again a warming period. As in the Corsica Channel time series, also at the DYFAMED station within one year the time series reached both its absolute maximum and its absolute minimum, suggesting dramatic changes occurring over recent years. The maximum heat import from the EMED was recorded in the Sicily Channel in April 2003 (see also the CTD time series for reference in Schroeder et al., 2006, their Fig. 3) while in the Corsica Channel the highest $\theta$ was reached in November 2004 and in the Ligurian subbasin in March 2004. Thus the sudden $\theta$ decrease seems to have started earlier in the Ligurian subbasin than in the Corsica Channel (even if the gap of the Corsica Channel series just during this time does not allow a high precision in the time lag estimate). Herrmann et al. (2010) suggested that the absence of DWF events during the milder '90s favoured the progressive accumulation of heat and salt in the intermediate layer, which then have been transferred to the new deep waters formed in early 2005 (Schroeder et al., 2010; Zunino et al., 2012). What is well evident is that also the heat imported from the EMED through the Sicily Channel decreased during the same period. Finally, the return of a warming period in the intermediate layer started in May 2006 in the Corsica Channel and one month later at the DYFAMED station (June 2006). A similar pattern, but less exaggerated, appears in the Corsica Channel between 1995 and 1999, which was also a year when a deep layer of anomalous WMDW with slightly higher $\theta$ and $S$ was formed (CIESM, 2009), although much less important than in the case of 2005.

The experience of the propagation of the EMT from the EMED demonstrates that straits and channels are suitable points to provide early warning of anomaly propagation. In the case of a fixed-depth monitoring, it remains unclear whether the low frequency cycles are associated to actual water mass changes, to variations of the depth of the water masses' cores or to the vertical displacement of the interface between different water masses. Nevertheless repeat CTD data collected twice per year in the surroundings of the mooring's site confirm this pattern when looking at the salinity maximum (the LIW core) properties (Schroeder et al., 2006). Important questions arising from these observations regard the origin of such oscillation in the LIW properties coming from the EMED interior, whether there is still any connection with the EMT or with the production of warm and salty Cretan Intermediate Water, or if the LIW formed in the Levantine subbasin shows similar trends and why (Gacic et al., 2013).

\section{Concluding remarks}

The ultimate goal of HC is not to provide complete information about the whole Mediterranean Sea, but rather to provide continuous high quality data in specific locations that may be considered representative for a certain region or regime, or where peculiar processes occur. Such continuous time series can then be employed to detect long-term variations, abrupt changes and events, and also to motivate, validate and improve adequate numerical simulations. The HC monitoring strategy is based on (i) permanency, to address the long-term variability, key sites to address specific processes, (ii) simplicity of logistics with a local management and short ship-time required for maintenance, and (iii) simple instrumentation (short moorings generally a few meters above the seafloor, supporting self contained, autonomous, high-quality CTDs). Moorings are located in key places to track the signals indicative of specific processes driving the Mediterranean functioning, especially in straits and channels and in regions where DWF occurs, either open-sea convection or shelf cascading. While it is likely that $\mathrm{HC}$ will remain a long-lasting challenge, the precise monitoring of the $\theta$ and $S$ is already providing reference data. The first results show that the HC strategy is a valid one and that it is achieving the objectives for which it was conceived. The huge data set will be even more exploitable in the years to come, with longer time series, both considering single time series but mainly combining data coming from different locations.

Future commitments to improve the HC network comprise the inclusion of moorings in other key regions, which are not currently monitored, possibly including additional institutes and favouring the participation of partners from the southern Mediterranean shore. The joining of a new partner to the network is done on a volunteer basis, and interested new mooring managers just need to contact the coordinators. Missing sites that deserve to be monitored to achieve the objectives of the HC Programme could be for instance: (i) the AW flow between WMED and EMED, in the middle of the Sicily Channel, close to Malta (such a mooring site is already planned by the Physical Oceanography Unit - University of Malta), (ii) other Cretan straits as well as the Bosphorus, (iii) other known or potential DWF sites, such as the Rhodes Gyre (Malanotte-Rizzoli et al., 1996), the northern Adriatic (Orlić et al., 1992), the Gulf of Gabes and the Tripoli canyon 
(Gasparini et al., 2008; CIESM, 2009), (iv) the along-slope southern sector of the Mediterranean. Existing sensors on long-term observatories should be carefully calibrated and in general there is strong need of increased uniformity within $\mathrm{HC}$, with common sampling strategies (sampling frequency, processing, calibration frequency, archiving) and the set-up of an $\mathrm{HC}$ database and meta-database. The common access to all time series would support efforts for linking the signals observed in both basins and at their connecting points in order to get a comprehensive picture of the functioning of the Mediterranean. Finally, the addition of supplementary sensors to the CTDs (pressure systematically, oxygen and turbidity recommended) would be a major improvement of the network, as well as the complementary use of moored vertical CTD profilers.

Systematic assessments of hydrological variability in relation to climate and to changes in biogeochemical processes and biodiversity are crucial to understand the mode of response/functioning of the marine ecosystem (e.g. Company et al., 2008). Despite their scientific value, long-term records are widely lacking in the Mediterranean but also at the global scale. Send et al. (2010) delineated the main reasons for them being so rare. First, they seem to be recognized as valuable when they are needed, which means that in a non-prospective view they are given lower priorities (in terms of funding) with respect to new technologies or innovative working hypotheses. Second, maintaining long-term observatories, especially in the deep sea, is a very expensive (and risky) task. Finally, the promotion of a shared use of expensive observatories has not effectively been undertaken.

The main advantage of coordinating single observation sites under the same umbrella of $\mathrm{HC}$ is the creation of a user community, an essential step to assure a long-term maintenance of those sites. This is why the HC Programme should enhance interactions among operators at regular meetings, in order to allow for exchange of expertise and ideas, leading to the development of common approaches and technologies, mutual support and sharing of efforts (Send et al., 2010). Further, data from a network of observational sites, for which uniformity and continuity is assured, rather than from a sum of sites, are much more useful for other communities, such as modelers or remote sensing users, for the implementation of validation procedures (Send et al., 2010).

The Mediterranean, being a direct and continuous source of warm and salty intermediate water, plays a substantial role in the heat content and water formation processes in the northern Atlantic and thus in the density driven circulation of the world's oceans (Candela, 2001). Hence, understanding the interannual variability of the Mediterranean Sea itself, has a more global importance than previously thought (Millot, 2007).

Acknowledgements. This is a contribution to the CIESM HYDROCHANGES Programme (http://www.ciesm.org/marine/ programs/hydrochanges.htm), which has been initiated by one of the authors (CM). We thank Frederic Briand, Director General of CIESM (the Mediterranean Science Commission), for his continuing support given to the programme since its origin. The authors thank the Collaboration of the ANTARES deep sea observatory for providing CTD time series data. In addition, the authors acknowledge the Observatoire Océanologique de Villefranche sur Mer Service d'Observation and CNRS-INSU for providing the DYFAMED monthly CTD time series shown for comparison with the HC time series in Fig. 16, as well as the Royal Navy of Morocco for their services.

Edited by: N. Pinardi

\section{References}

Ambar, I., Serra, N., Brogueira, M. J., Cabeçadas, G., Abrantes, F., Freitas, P., Gonçalves, C., and Gonzalez, N.: Physical, Chemical and Sedimentological Aspects of the Mediterranean Outflow Off Iberia, Deep-Sea Res. II, 49, 4163-4177, 2002.

ANTARES Collaboration: First results of the Instrumentation Line for the deep-sea ANTARES neutrino telescope, Astropart. Phys., 26, 314-324, 2006.

Artegiani, A., Paschini, E., Russo, A., Bregant, D., Raicich, F., and Pinardi, N.: The Adriatic Sea General Circulation, Part I: AirSea Interactions and Water Mass Structure, J. Phys. Oceanogr., 27, 1492-1514, 1997.

Astraldi, M. and Gasparini, G. P.: Influence of the climatic conditions on the winter fluxes in the Corsican channel, in: The physical oceanography of sea straits, edited by: Pratt, L. J., Kluwer Acad. Publ., Dordrecht Netherlands, 211-224, 1990.

Astraldi, M. and Gasparini, G. P.: The seasonal characteristics of the circulation in the North Mediterranean Basin and their relationship with the atmospheric-climatic conditions, J. Geophys. Res., 97, 9531-9540, 1992.

Astraldi, M., Galli, C., Gasparini, G. P., Lazzoni, E., and Manzella, G. M. R.: The Janus Experiment, Istituto Dinamica Grandi Masse, S.O. Technical Report TR140, 40 pp., 1987.

Astraldi, M., Balopoulos, S., Candela, J., Font, J., Gačić, M., Gasparini, G. P., Manca, B., Theocharis, A., and Tintoré, J.: The role of straits and channels in understanding the characteristics of Mediterranean circulation, Prog. Oceanogr., 44, 65-108, 1999.

Baringer, M. O. N. and Price, J.: Momentum and energy balance of the Mediterranean outflow, J. Phys. Oceanogr., 27, 1678-1692, 1997.

Ben Ismail, S., Sammari, C., Gasparini, G. P., Béranger, K., Brahim, M., and Aley, L.: Water masses exchanged through the Channel of Sicily: Evidence for the presence of new water masses on the Tunisian side of the channel, Deep-Sea Res. I, 63, 65-81, 2012.

Bensi, M., Cardin, V., and Rubino, A.: Thermohaline variability and mesoscale dynamics observed at the E2M3A deep-site in the Southern Adriatic Sea, submitted to EGU BOOKS programs (Book series: "The Mediterranean Sea: Temporal Variability and Spatial Patterns"), 2013.

Béthoux, J. P. and Gentili, B.: The Mediterranean Sea, coastal and deep-sea signatures of climatic and environmental changes, J. Marrine Syst., 7, 383-394, 1996.

Béthoux, J. P. and Gentili, B.: Functioning of the Mediterranean Sea: past and present changes related to fresh water input and 
climatic changes, J. Marine Syst., 20, 33-47, 1999.

Béthoux, J. P., Gentili, B., and Tailliez, D.: Warming and freshwater budget change in the Mediterranean since the 1940s, their possible relation to the greenhouse effect, Geophys. Res. Lett., 25, 1023-1026, 1998.

Bignami, F., Salusti, E., and Schiarini, S.: Observations on a bottom vein of dense water in the Southern Adriatic and Ionian Seas, J. Geophys. Res., 95, 7249-7259, 1990.

Borzelli, G. L. E., Gačić, M., Cardin, V., and Civitarese, G.: Eastern Mediterranean Transient and reversal of the Ionian Sea circulation, Geophys. Res. Lett., 36, L15108, doi:10.1029/2009GL039261, 2009.

Bouzinac, C., Font J., and Millot, C.: Hydrology and currents observed in the Channel of Sardinia during the PRIMO-1 experiment from Nov. 1993 to Oct. 1994, J. Marine Syst., 20, 333-355, 1999.

Bray, N. A., Ochoa, J., and Kinder, T. H.: The role of the interface in exchange through the strait of Gibraltar, J. Geophys. Res., 100, 10755-10766, 1995.

Bryden, H. L., Candela, J., and Kinder, T. H.: Exchange through the Strait of Gibraltar, Prog. Oceanogr., 33, 201-248, 1994.

Canals, M., Puig, P., Durrier-de-Madron, X., Heussner, S., Palanques, A. and Fabres, J.: Flushing submarine canyons, Nature, 444, 354-357, doi:10.1038/nature05271, 2006.

Candela, J.: Mediterranean water and the global circulation, in: Ocean Circulation and Climate: Observing and Modeling the Global Ocean, edited by: Siedler, G., Church, J., and Gould, J., Academic Press, 419-429, 2001.

Candela, J., Winant, C., and Ruiz, A.: Tides in the Strait of Gibraltar. J. Geophys Res., 95, 7313-7335, 1990.

Cardin, V. and Gačić, M.: Long-term heat flux variability and winter convection in the Adriatic Sea, J. Geophys. Res., 108, 8103, doi:10.1029/2002JC001645, 2003.

Cardin, V. and Gačić, M.: Are decadal variations of Adriatic thermohaline properties related to the Eastern Mediterranean Transient (EMT)?, in: CIESM,2008, Climate Warming and Related Changes in Mediterranean Marine Biota, edited by: Briand, F., No. 35 in CIESM Workshop Monographs, 152 pp., Monaco, 2008.

Cardin, V., Bensi, M., and Pacciaroni, M.: Variability of water mass properties in the last two decades in the Southern Adriatic Sea with emphasis on the period 2006-2009, Cont. Shelf Res., 31, 951-965, doi:10.1016/j.csr.2011.03.002, 2011.

Castro, M., Garcia-Rodriguez, J., Gonzalez-Vida, J., Macias, J., Pares, C., and Vazquez-Cendon, M.: Numerical simulation of two-layer shallow water flows through channels with irregular geometry, J. Comput. Phys., 195, 202-235, 2004.

CIESM: Report of the second Round Table on Mediterranean Water Mass Acronyms, in: Acts of the 36th CIESM Congress, available at: www.ciesm.org/catalog/WaterMassAcronyms.pdf, (last access: 12 April 2012), 2001.

CIESM: Tracking long-term hydrological change in the Mediterranean Sea, in: CIESM Workshop Series, no. 16, 134 pp, Monaco, 2002.

CIESM: Towards an integrated system of Mediterranean marine observatories, in: CIESM Workshop Series, no. 34, 144 pp., Monaco, 2008.

CIESM: Dynamics of Mediterranean deep waters, in: CIESM Workshop Series, no. 38, 132 p., Monaco, 2009.
CIESM: Designing Med-SHIP: a Program for repeated oceanographic surveys, in: CIESM Workshop Series, no. 43, 162 pp., Supetar, 2011.

Company, J. B., Puig, P., Sardà, F., Palanques, A., Latasa, M., and Scharek, R.: Climate Influence on Deep Sea Populations. PLoS ONE, 3, e1431, doi:10.1371/journal.pone.0001431, 2008.

Crépon, M., Wald, L., and Monget, M.: Low-frequency waves in the Ligurian Sea during December 1977, J. Geophys Res., 87, 595-600, doi:10.1029/JC087iC01p005, 1982.

Crépon, M., Boukthir, M., Barnier, B., and Aikman III, F.: Horizontal ocean circulation forced by deep water formation. Part I: an analytical study. J. Phys. Oceanogr., 19, 1781-1792, 1989.

Demirov, E. and Pinardi, N.: The Simulation of the Mediterranean Sea circulation from 1979 to 1993 . Part I: The interannual variability, J. Marine Syst., 33-34, 23-50, 2002.

Farmer, D. M. and Armi, L.: The flow of Atlantic Water through the Strait of Gibraltar, Prog. Oceanogr., 21, 1-105, 1988.

Font, J., Puig, P., Salat, J., Palanques, A., and Emelianov, M.: Sequence of hydrographic changes in NW Mediterranean deep water due to the exceptional winter of 2005. Sci. Mar., 71(2), 339346, 2007.

Fuda, J.-L., Etiope, G., Millot, C., Faveli, C., Calcara, M., Smriglio, G. and Boschi, E.: Warming, salting and origin of the Tyrrhenian deep water. Geophys. Res. Lett., 29(18), 1886 , doi:10.1029/2001gl014072, 2002.

Gačić, M., Poulain, P.-M., Zore-Armanda, M., and Barale V.: Overview in Physical Oceanography of the Adriatic Sea: Past, Present and Future, edited by: Cushman-Roisin, B., M. Gačić, P. Poulain, and A. Artegiani, Kluwer Academic Publishers, 320 pp., 2001.

Gačić, M., Civitarese, G., Miserocchi, S., Cardin, V., Crise A., and Mauri E.: The open-ocean convection in the Southern Adriatic: a controlling mechanism of the spring phytoplankton bloom, Cont. Shelf Res., 22, 1897-1908, 2002.

Gačić, M., Borzelli, G. L. E., Civitarese, G., Cardin, V., and Yari, S.: Can internal processes sustain reversals of the ocean upper circulation?: the Ionian Sea example, Geophys. Res. Lett., 37, L09608, doi:10.1029/2010GL043216, 2010.

Gačić, M., Civitarese, G., Borzelli, G. L. E., Kovačević, V., Poulain, P.-M., Theocharis, A., Menna, M., Catucci, A., and Zarokanellos, N.: On the relationship between the decadal oscillations of the Northern Ionian Sea and the salinity distributions in the Eastern Mediterranean, J. Geophys. Res., 116, C12002, doi:10.1029/2011JC007280, 2011.

Gačić, M., Schroeder, K., Civitarese, G., Cosoli, S., Vetrano, A., and Eusebi Borzelli, G. L.: Salinity in the Sicily Channel corroborates the role of the Adriatic-Ionian Bimodal Oscillating System (BiOS) in shaping the decadal variability of the Mediterranean overturning circulation, Ocean Sci., 9, 83-90, doi:10.5194/os-983-2013, 2013.

García-Lafuente, J., Vargas, J. M., Plaza, F., Sarhan, T., Candela, J., and Baschek, B.: Tide at the eastern section of the Strait of Gibraltar, J. Geophys. Res., 105, 14197-14213, 2000.

García-Lafuente, J., Sánchez Román, A., Díaz del Río, G., Sannino, G., and Sánchez-Garrido, J. C.: Recent observations of seasonal variability of the Mediterranean outflow in the Strait of Gibraltar, J. Geophys. Res., 112, C10005, doi:10.1029/2006JC003992, 2007. 
García-Lafuente, J., Delgado, J., Sánchez-Román, A., Soto, J., Carracedo, L., and Díaz del Río, G.: Interannual variability of the Mediterranean outflow observed in Espartel sill, western Strait of Gibraltar, J. Geophys. Res., 114, C10018, doi:10.1029/2009JC005496, 2009.

García-Lafuente, J., Sánchez-Román, A., Naranjo, C., and SánchezGarrido, J. C.: The very first transformation of the Mediterranean outflow in the Strait of Gibraltar, J. Geophys. Res., 116, C07010, doi:10.1029/2011JC006967, 2011.

Garrett, C., Outerbridge, R., and Thompson, K.: Interannual Variability in Mediterranean Heat and Buoyancy Fluxes. J. Climate, 6, 900-910, 1993.

Gasparini, G. P., Ortona, A., Budillon, G., Astraldi, M., and Sansone, E.: The effect of the Eastern Mediterranean Transient on the hydrographic characteristics in the strait of Sicily and in the Tyrrhenian Sea, Deep-Sea Res. I, 52, 915-935, 2005.

Gasparini, G. P., Bonanno, A., Zgozi, S., Basilone, G., Borghini, M., Buscaino, G., Cuttitta, A., Essarbout, N., Mazzola, S., Patti, B., Ramadan, A. B., Schroeder, K., Bahri, T., and Massa, F.: Evidence of a dense water vein along the Libyan continental margin, Ann. Geophys., 26, 1-6, doi:10.5194/angeo-26-1-2008, 2008.

Giorgi, F.: Climate change hot-spots, Geophys. Res. Lett., 33, L08707, doi:10.1029/2006GL025734, 2006.

Grancini, G. F. and Michelato, A.: Current structure and variability in the Strait of Sicily and adjacent area, Ann. Geophys. Ser. B, 5, 75-88, 1987.

Herbaut C., Mortier, L., and Crépon, M.: A sensitivity study of the general circulation of the western Mediterranean, Part II: the response to atmospheric forcing, J. Phys. Oceanogr., 27, 21262145, 1997.

Herrmann, M., Sevault, F., Beuvier, J., and Somot, S.: What induced the exceptional 2005 convection event in the Northwestern Mediterranean basin? Answers from a modeling study, J. Geophys. Res., 115, C12051, doi:10.1029/2010jc006162, 2010.

Josey, S. A.: Changes in the heat and freshwater forcing of the Eastern Mediterranean and their influence on deep water formation, J. Geophys. Res., 108, 3237, doi:10.1029/2003jc001778, 2003.

Kinder, T. H. and Bryden, H. L.: Aspiration of deep waters through strait, in: The Physical Oceanography of Sea Straits, Kluwer Academic. Publ., London, 587 pp., 1990.

Klein, B., Roether, W., Manca, B. B., Bregant, D., Beitzel, V., Kovacevich, V. and Luchetta, A.: The large deep water transient in the eastern Mediterranean. Deep-Sea Res. I, 46, 371-414, 1999.

Kontoyiannis, H., Balopoulos, E., Gotsis-Skretas, O., Pavlidou, A., Assimakopoulou, G. and Papageorgiou, E.: The hydrology and biochemistry of the Cretan Straits (Antikithira and Kassos Straits) revisited in the period June 1997-May 1998, J. Marine Syst., 53, 37-57, 2005.

Krahmann, G. and Schott, F.: Long term increases in western Mediterranean salinities and temperatures: anthropogenic and climatic sources, Geophys. Res. Lett., 25, 4209-4212, 1998.

Krivosheya, V. G. and Ovchinnikov, I. M.: Peculiarities in the geostrophic circulation of the waters of the Tyrrhenian Sea, Oceanology, 13, 822-827, 1973.

Lascaratos, A., Roether, W., Nittis, K., and Klein, B.: Recent changes in deep water formation and spreading in the eastern Mediterranean Sea: a review, Prog. Oceanogr., 44, 5-36, 1999.

Leaman, K. D. and Schott, F. A.: Hydrographic structure of the convection regime in the Gulf of Lions: Winter 1987, J. Phys.
Oceanogr., 21, 575-598, 1991.

López-Jurado, J., González-Pola, C., and Vélez-Belchi, P.: Observation of an abrupt disruption of the longterm warming trend at the Balearic Sea, Western Mediterranean sea, in summer 2005, Geophys. Res. Lett., 32, L24606, doi:10.1029/2005g1024430, 2005.

Louanchi, F., Boudjakdji, M., and Nacef, L.: Decadal changes in surface carbon dioxide and related variables in the Mediterranean Sea as inferred from a coupled data diagnostic model approach, ICES J. Mar. Sci., 66, 1538-1546, 2009.

Malanotte-Rizzoli, P.: The Northern Adriatic Sea as a prototype of convection and water mass formation on the continental shelf, in: Deep Convection and Deep-water Formation in the Oceans, edited by: Chu, P. C. and Gascard, J. P., Elsev. Oceanogr. Serie., 57, 229-239, 1991.

Malanotte-Rizzoli, P., Robinson A. R., Roether, W., Manca, B., Bergamasco, A., Brenner, S., Civitarese, G., Georgopoulos, D., Haley, P. J., Kioroglou, S., Kontoyiannis, H., Kress, N., Latif, M. A., Leslie, W. G., Ozsoy, E., Ribera d'Alcala, M., Salihoglu, I., Sansone, E., and Theocharis, A.: Experiment in eastern Mediterranean probes origin of deep water masses, Eos Trans. AGU, 77, 305, doi:10.1029/96EO00212, 1996.

Malanotte-Rizzoli, P., Manca, B.B., Ribera d'Alcala, M., Teocharis, A., Bergamasco, A., Bregant, D., Budillon, G., Civitarese, G., Georgopoulos, D., Michelato, A., Sansone, E., Scarazzato, P., and Souvermezoglou, E.: A synthesis of the Ionian Sea hydrography, circulation and water mass pathways during POEM-Phase I, Prog. Oceanogr., 39, 153-204, 1997.

Malanotte-Rizzoli, P., Manca, B. B., Ribera d'Alcala, M., Theocharis, A., Brenner, A., Budillon, G., and Ozsoy, E.: The Eastern Mediterranean in the 80s and in the 90s: The big transition in the intermediate and deep circulations, Dynam. Atmos. Oceans, 29, 365-395, 1999.

Manca, B. B., Kovačević, V., Gačić, M., and Viezzoli, D.: Dense water formation in the Southern Adriatic Sea and spreading into the Ionian Sea in the period 1997-1999, J. Marine Syst., 33/34, 133-154, 2002.

Manzella, G. M. R., Gasparini, G. P., and Astraldi, M.: Water exchange between the Eastern and Western Mediterranean through the Strait of Sicily, Deep-Sea Res., 35, 1021-1035, 1988.

Marty, J. C. and Chiavérini, J.: Hydrological changes in the Ligurian Sea (NW Mediterranean, DYFAMED site) during 1995-2007 and biogeochemical consequences, Biogeosciences, 7, 21172128, doi:10.5194/bg-7-2117-2010, 2010.

MEDAR Group: Mediterranean and Black Sea Database of Temperature, Salinity and Biochemical Parameters and Climatological Atlas (CD-ROM), edited by: Inst. Fr. de Rech. pour l'Exploit. de la Mer, Plouzane, France, available at: http://www.ifremer.fr/ sismer/program/medar/, 2002 .

MEDOC Group: Observation of formation of deep water in the Mediterranean Sea in 1969, Nature, 227, 1037-1040, 1970.

Millot, C.: Circulation in the western Mediterranean Sea, J. Marine Syst., 20, 423-442, 1999.

Millot C.: Interannual salinification of the Mediterranean inflow, Geophys. Res. Lett., 34, L21609, doi:10.1029/2007GL031179, 2007.

Millot, C.: Short-term variability of the Mediterranean in- and out-flows, Geophys. Res. Lett., 35, L15603, doi:10.1029/2008GL033762, 2008. 
Millot C.: Another description of the Mediterranean outflow, Progr. Oceanogr., 82, 101-124, 2009.

Millot, C.: The LIW characteristics: an astounding general misunderstanding. Scientia Marina, in press, 2013.

Millot, C.: The Mediterranean Sea in- and out-flows' heterogeneities, Prog. Oceanogr., submitted, 2013.

Millot, C. and Briand, F.: Executive summary, in: Tracking Long Term Hydrological Change in the Mediterranean Sea, edited by: Briand, F., CIESM Workshop Series no. 16., 7-14, 2002.

Millot, C. and García-Lafuente, J.: About the seasonal and fortnightly variabilities of the Mediterranean outflow, Ocean Sci., 7, 421-428, doi:10.5194/os-7-421-2011, 2011.

Millot, C. and Taupier-Letage, I.: Circulation in the Mediterranean Sea, The Handbook of Environmental Chemistry, K, 29-66, doi:10.1007/b107143, 2005.

Millot, C., Candela, J., Fuda, J.-L., and Tber, Y.: Large warming and salinification of the Mediterranean outflow due to changes in its composition, Deep-Sea Res., 53, 656-666, doi:10.1016/j.dsr.2005.12.017, 2006.

Orlić, M., Gačić, M., and La Violette, P. E.: The currents and circulation of the Adriatic Sea, Oceanol. Ac., 15, 109-124, 1992.

Ovchinnikov, I. M., Krivosheya V. G., and Udodov A. I.: Formation of deep eastern Mediterranean water in the Adriatic Sea, Oceanology, 25, 704-707, 1985.

Painter, S. C. and Tsimplis, M. N.: Temperature and salinity trends in the upper waters of the Mediterranean Sea as determined from the MEDATLAS dataset, Cont. Shelf Res., 23, 1507-1522, 2003.

Palanques, A., Durrieu de Madron, X., Puig, P., Fabres, J., Guillén, J., Calafat, A., Canals, M., Heussner, S., and Bonnin, J.: Suspended sediment fluxes and transport processes in the Gulf of Lions submarine canyons, The role of storms and dense water cascading, Mar. Geol., 234, 43-61, doi:10.1016/j.margeo.2006.09.002, 2006.

Palanques, A., Puig, P., Latasa, M., and Scharek, R.: Deep sediment transport induced by storms and dense shelf-water cascading in the northwestern Mediterranean basin, Deep-Sea Res., 56, 425434, doi:10.1016/j.dsr.2008.11.002, 2009.

Parrilla, G., Kinder, T. H., and Preller, R. H.: Deep and intermediate Mediterranean water in the western Alboran Sea, Deep-Sea Res., 33, 55-88, 1986.

Pascual, J., Salat, J., and Palau, M.:. Evolucion de la temperatura del mar entre 1973 y 1994, cerca de la costa catalana, in: Int. Coll. Okeanos, 23-28, Montpellier, 1995.

Pascual, A., Pujol, M.-I., Larnicol, G., Le Traon, P.-Y., and Rio, M.-H.: Mesoscale mapping capabilities of multisatellite altimeter missions: first results with real data in the Mediterranean Sea, J. Marine Syst., 65, 190-211, 2007.

Pinardi, N. and Masetti, E.: Variability of the large scale general circulation of the Mediterranean Sea from observations and modelling: a review. Palaeogeography, Palaeoclimatology, Palaeoecology, 158, 153-173, 2000.

Pinardi, N., Korres, G., Lascaratos, A., Roussenov, V., and Stanev, E.: Numerical simulation of the interannual variability of the Mediterranean Sea upper ocean circulation, Geophys. Res. Lett., 24, 425-428, 1997.

Potter, R. A., and Lozier, M. S.: On the warming and salinification of the Mediterranean outflow waters in the North Atlantic, Geophys. Res. Lett., 31, L01202, doi:10.1029/2003GL018161, 2004.
Puig, P., Palanques, A., Orange, D. L., Lastras, G., and Canals, M.: Dense shelf water cascades and sedimentary furrow formation in the Cap de Creus Canyon, northwestern Mediterranean Sea, Cont. Shelf Res., 28, 2017-2030, 2008.

Puig, P., Durrieu de Madron, X, Salat, J., Schroeder, K., Martín, J., Karageorgis, A. P., Palanques, A., Roullier, F., Lopez-Jurado J. L., Emelianov, M., Moutin, T., and Houpert, L.: Thick bottom nepheloid layers in the western Mediterranean generated by deep dense shelf water cascading, Prog. Oceanogr., in press, 2013.

Reverdin, G., Kestenare, E., Frankignoul, C., and Delcroix, T.: Surface salinity in the Atlantic Ocean $\left(30^{\circ} \mathrm{S}-50^{\circ} \mathrm{N}\right)$. Prog. Oceanogr., 73, 311-340, 2007.

Ribó, M., Puig, P., Palanques, A., and Lo Iacono, C.: Dense shelf water cascades in the Cap de Creus and Palamós submarine canyons during winters 2007 and 2008, Mar. Geol., 284, 175188, 2011.

Rixen, M., Bekers, J.-M., Levitus, S., Antonov, J., Boyer, T., Maillard, C., Fichaud, M., Balopoulos, E., Iona, S., Dooley, H., García, M. J., Manca, B., Girgetti, A., Manzzella, G., Mikhailov, M., Pinardi, N., and Zavatarelli, M.: The Western Mediterranean Deep Water: a proxy for climate change, Geophys. Res. Lett., 32, L12608, doi:10.1029/2005g1022702, 2005.

Roether, W., Manca, B. B., Klein, B., Bregant, D., Georgopoulos, D., Beitzel, V., Kovacevic, V., and Luchetta, A.: Recent changes in Eastern Mediterranean Deep waters, Science, 271, 333-335, 1996.

Roether, W., Klein, B., Manca, B. B., Thecharis, A., and Kioroglou, S.: Transient Eastern Mediterranean Deep waters in response to the massive dense water output of the Aegean Sea in the 1990s, Prog. Oceanogr., 74, 540-571, 2007.

Rohling, E. J. and Bryden, H.: Man-induced salinity and temperature increase in the western Mediterranean deep water, J. Geophys. Res., 97, 11191-11198, 1992.

Rubino, A. and Hainbucher, D.: A large abrupt change in the abyssal water masses of the eastern Mediterranean, Geophys. Res. Lett., 34, L23607, doi:10.1029/2007GL031737, 2007.

Sammari, C., Millot, C., Taupier-Letage, I., Stefani, A., and Brahim, M.: Hydrological characteristics in the Tunisia-Sardinia-Sicily area during spring 1995, Deep-Sea Res. I, 46, 1671-1703, 2007.

Sánchez-Román, A., Sannino, G., García-Lafuente, J., Carillo, A., and Criado-Aldeanueva, F.: Transport estimates at the western section of the Strait of Gibraltar: A combined experimental and numerical modeling study, J. Geophys. Res., 114, C06002, doi:10.1029/2008JC005023, 2009.

Sannino, G., Bargagli, A., and Artale, V.: Numerical modeling of the semidiurnal tidal exchange through the Strait of Gibraltar, J. Geophys. Res., 109, C05011, doi:10.1029/2003jc002057, 2004.

Sannino, G., Pratt, L., and Carillo, A.: Hydraulic criticality of the exchange flow through the Strait of Gibraltar, J. Phys. Oceanogr., 39, 2779-2799, doi:10.1175/2009jpo4075.1, 2009.

Schroeder, K., Gasparini, G. P., Tangherlini, M., and Astraldi, M.: Deep and intermediate water in the Western Mediterranean under the influence of the Eastern Mediterranean Transient, Geophys. Res. Lett., 33, L21607, doi:10.1029/2006g1027121, 2006.

Schroeder, K., Ribotti, A., Borghini, M., Sorgente, R., Perilli, A., and Gasparini, G. P.: An extensive western Mediterranean deep water renewal between 2004 and 2006, Geophys. Res. Lett., 35, L18605, doi:10.1029/2008GL035146, 2008. 
Schroeder, K., Josey, S. A., Herrmann, M., Grignon, L., Gasparini, G. P., and Bryden, H. L.: Abrupt warming and salting of the Western Mediterranean Deep Water after 2005: atmospheric forcings and lateral advection, J. Geophys. Res., 115, C08029, doi:10.1029/2009jc005749, 2010.

Schroeder, K., Garcìa-Lafuente, J., Josey, S. A., Artale, V., Buongiorno Nardelli, B., Carrillo, A., Gačić, M., Gasparini, G.P., Herrmann, M., Lionello, P., Ludwig, W., Millot, C., Özsoy, E., Pisacane, G., Sánchez-Garrido, J. C., Sannino, G., Santoleri, R., Somot, S., Struglia, M., Stanev, E., Taupier-Letage, I., Tsimplis, M. N., Vargas-Yáñez, M., Zervakis, V., and Zodiatis, G.: Chapter 3: Circulation of the Mediterranean Sea and its Variability, in: The Climate of the Mediterranean Region: From the past to the future, edited by: Lionello, P., Elsevier Insights, Amsterdam, 2012.

Send, U., Font, J., and Mertens, C.: Recent observation indicates convection's role in deep water circulation, EOS Transactions AGU, 77, 61-65, 1996.

Send, U., Font, J., Krahmann, G., Millot, C., Rhein, M., and Tintoré, J.: Recent advances in observing the physical oceanography of the western Mediterranean Sea, Prog. Oceanogr., 44, 37-64, 1999.

Send, U., Weller, R. A., Wallace, D., Chavez, F., Lampitt, R. L., Dickey, T., Honda, M., Nittis, K., Lukas, R., McPhaden, M., and Feely, R.: OceanSITES, in: Proceedings of OceanObs'09: Sustained Ocean Observations and Information for Society (Vol. 2), Venice, Italy, 21-25 September 2009, edited by: Hall, J., Harrison, D. E., and Stammer, D., ESA Publication WPP-306, doi:10.5270/OceanObs09.cwp.79, 2010.

Taupier-Letage, I. and Millot, C.: General hydrodynamical features in the Ligurian Sea inferred from the Dyomé experiment, Oceanol. Acta, 9, 119-131, 1986.

Taupier-Letage, I. and the EGYPT/EGITTO Teams: New elements on the surface circulation in the eastern basin of the Mediterranean. Rapp. Comm. int. Mer Medit., 38, 204, 2007.

Theocharis, A., Georgopoulos, D., Karagevrekis, P., Iona, A., Perivoliotis, L., and Charalambidis, N.: Aegean influence in the deep layers of the Eastern Ionian sea, Rapp. Comm. int. Mer Medit, 33, 235, 1992.
Theocharis, A., Nittis, K., Kontoyiannis, H., Papageeorgiou E., and Balopoulos, E.: Climatic changes in the Aegean Sea influence the Eastern Mediterranean themohaline circulation (1986-1997), Geophys. Res. Lett., 26, 1617-1620, 1999.

Tsimplis, M. N. and Baker, T. F.: Sea level drop in the Mediterranean Sea: An indicator of deep water salinity and temperature changes?, Geophys. Res. Lett., 27, 1731-1734, 2000.

Vargas-Yáñez, M., Salat, J., Fernández, M. L., López-Jurado, J. L., Pascual, J., Ramírez, T., Cortés, D., and Franco, I.: Trends and time variability in the northern continental shelf of the Western Mediterranean, J. Geophys. Res., 110, C10019, doi:10.1029/2004JC002799, 2005.

Vargas-Yáñez, M., Moya, F., Tel, E., García-Martínez, M. C., Guerber, E., and Bourgeon, M.: Warming and salting in the western Mediterranean during the second half of the 20th century: inconsistencies, unknowns and the effect of data processing, Sci. Mar., 73, 7-28, 2009.

Vargas-Yáñez, M., Zunino, P., Benali, A., Delpy, M., Pastre, F., Moya, F., García-Martínez, M. C., and Tel, E.: How much is the western Mediterranean really warming and salting?, J. Geophys. Res., 115, C04001, doi:10.1029/2009JC005816, 2010.

Vetrano, A., Gasparini, G. P., Molcard, R., and Astraldi, M.: Water flux estimates in the central Mediterranean Sea from an inverse box model, J. Geophys. Res., 109, C01019, doi:10.1029/2003JC001903, 2004.

Vetrano, A., Napolitano, E., Iacono, R., Schroeder, K., and Gasparini, G. P.: Tyrrhenian Sea circulation and water mass fluxes in spring 2004: observations and model results, J. of Geophys. Res., 15, C06023, doi:10.1029/2009JC005680, 2010.

Zodiatis, G. and Gasparini, G. P.: Thermohaline staircase formation in the Tyrrhenian Sea, Deep-Sea Res. I, 43, 655-678, 1996.

Zunino, P., Schroeder, K., Vargas-Yáñez, M., Gasparini, G. P., Coppola, L., García-Martínez, M. C., and Moya-Ruiz, F.: Effects of the Western Mediterranean Transition 1 on the resident water masses: pure warming, pure freshening and pure heaving, J. Marine Syst., 96/97, 15-23, 2012. 